\title{
Interleukin 17 Family Cytokines: Signaling Mechanisms, Biological Activities, and Therapeutic Implications
}

\author{
Leticia Monin ${ }^{1}$ and Sarah L. Gaffen \\ Division of Rheumatology and Clinical Immunology, University of Pittsburgh, Pittsburgh, Pennsylvania 15261 \\ Correspondence: sarah.gaffen@pitt.edu
}

\begin{abstract}
The cytokines of the interleukin 17 (IL-17) family play a central role in the control of infections, especially extracellular fungi. Conversely, if unrestrained, these inflammatory cytokines contribute to the pathology of numerous autoimmune and chronic inflammatory conditions. Recent advances have led to the approval of IL-17A-blocking biologics for the treatment of moderate to severe plaque psoriasis, but much remains to be understood about the biological functions, regulation, and signaling pathways downstream of these factors. In this review, we outline the current knowledge of signal transduction and known physiological activities of IL-17 family cytokines. We will highlight in particular the current understanding of these cytokines in the context of skin manifestations of disease.
\end{abstract}

nterleukin (IL)-17A, the founding and most studied member of the IL-17 family, was cloned in 1993 and initially named cytotoxic T lymphocyte-associated antigen 8 (CTLA-8). Its sequence and predicted structure were markedly different from other known cytokines, but interestingly was homologous to an open reading frame (ORF) in the T-cell tropic Herpesvirus saimiri virus (Rouvier et al. 1993). A decade later, IL-17A took central stage with the discovery of Th17 cells as a T helper (Th) subset distinct from Th1 and Th2 cells (Langrish et al. 2005; Park et al. 2005). Five additional family members have been described, designated IL$17 \mathrm{~B}, \mathrm{C}, \mathrm{D}, \mathrm{E}$, and F. Of these, IL-17F shares the greatest degree of conservation to IL-17A (55\%) and is commonly produced by the same cell types. IL-17F was the first member of this family for which a crystallographic structure was elucidated. Interestingly, structural analysis re- vealed the formation of a cysteine-knot fold, similar to that adopted by neurotrophins such as nerve growth factor (NGF) (Hymowitz et al. 2001). IL-17E, also known as IL-25, displays the lowest degree of sequence conservation (16\%) (Huang et al. 2015). In turn, other family members derive from different cellular sources and are associated with varying functions. IL-17A, IL-17F, IL-17C, and IL-17E function in host defense against pathogens and play various but not fully understood roles in mediating inflammation in autoimmune, allergic, and chronic inflammatory conditions. Given the central role of IL-17A in autoimmunity, much effort has focused on the development of neutralizing antibodies for therapeutic use. Indeed, IL-17Ablocking antibodies secukinumab and ixekizumab recently received U.S. Food and Drug Administration (FDA) approval for the treatment of psoriasis, ankylosing sponylitis (AS), and

\footnotetext{
${ }^{1}$ Present address: The Francis Crick Institute, London NW1 1AT, United Kingdom. Editors: Warren J. Leonard and Robert D. Schreiber

Additional Perspectives on Cytokines available at www.cshperspectives.org

Copyright (C) 2018 Cold Spring Harbor Laboratory Press; all rights reserved; doi: 10.1101/cshperspect.a028522 Cite this article as Cold Spring Harb Perspect Biol 2018;10:a028522
} 
psoriatic arthritis (PsA) (Langley et al. 2014; Gordon et al. 2016). Nonetheless, many aspects of IL-17A function, and especially of other cytokines in this family, remain poorly defined.

All known IL-17 family cytokines signal via a receptor family that is distinct from other known cytokine receptors (Yao et al. 1995). The IL-17R family contains five members, IL-17RA-E, all of which are single-pass transmembrane receptors with conserved structural features (Aggarwal and Gurney 2002). Specifically, all family members encode two extracellular fibronectin II-like domains and an intracellular SEFIR domain; the name alludes to the presence of this domain in SEF/IL-17RD and other IL-17 receptor proteins. The SEFIR is structurally related to the TIR domain found in the TLR/IL-1R family and is crucial for triggering downstream signaling events (see also the section "IL-17 Cytokine Signaling and Regulation") (Novatchkova et al. 2003). The prevailing paradigm for most IL-17 cytokines is that signaling occurs through heterodimeric receptors composed of a common IL-17RA chain and a second chain that determines ligand or signaling specificity. The second receptor chains are as follows: IL-17RC for IL-17A and IL-17F (Toy et al. 2006), IL-17RB for IL-17E (Rickel et al. 2008), and IL-17RE for IL-17C (Fig. 1) (Ramirez-Carrozzi et al. 2011). IL-17B is also reported to bind IL-17RB, albeit less strongly than IL-17E (Shi et al. 2000). In addition, the requirement for IL-17RA in IL$17 \mathrm{~B}$ signaling is still under debate, and the receptor for IL-17D remains undefined. Here, we review the current understanding of cellular sources of the IL-17 family of cytokines, signal transduction mechanisms that govern their function, and the cutaneous biological processes in which these cytokines participate.

\section{CELLULAR SOURCES OF IL-17 FAMILY CYTOKINES}

IL-17A and IL-17F

More than 30 years ago, the paradigm of Th differentiation postulated that two discrete Th populations, Th1 and Th2 cells, acquired the ability to produce canonical cytokines, and were thus "tuned" to control biologically dissimilar pathogens (Mosmann et al. 1986). Although a useful model, there were numerous discrepancies that called this view into question (Steinman 2007). Indeed, in 2005, a third Th cell subset was described that produced IL17A, IL-17F, as well as IL-21, IL-22, and granulocyte macrophage colony-stimulating factor (GM-CSF) (Park et al. 2005; Liang et al. 2006; Korn et al. 2007; Nurieva et al. 2007), and hence came to be known as "Th17." Like other Th subsets, naïve $\mathrm{CD} 4^{+} \mathrm{T}$ cells become committed to the Th17 lineage via cytokine cues received during antigen presentation in secondary lymphoid organs. For Th17 cells, this is a combination of IL-1b, IL-6, transforming growth factor $\beta$ (TGF- $\beta$ ), and IL-21 for initial commitment (Bettelli et al. 2006; Mangan et al. 2006; Veldhoen et al. 2006; Zhou et al. 2007) and IL-23 for full acquisition of their pathogenic capacity (Cua et al. 2003; Awasthi et al. 2009; McGeachy et al. 2009). Like Th1 and Th2 cells, Th17 cells express a lineage-determining "master" transcription factor, Roryt, which directs the production of their hallmark cytokines (Ivanov et al. 2006).

More recently, it has become clear that additional populations of cells are also important sources of IL-17A and IL-17F. These include $\mathrm{CD}^{+}$cytotoxic T (Tc) cells (He et al. 2006; Huber et al. 2013) and innate tissue-resident cells that are rapidly activated on injury or pathogenic insult. Among these innate subsets are $\gamma \delta$ T cells (including $\mathrm{Vg}^{+}{ }^{+}$and $\mathrm{Vg} 6^{+}$cells [Cua and Tato 2010]) innate lymphoid cells ([ILCs], specifically the ILC3 subset) (Villanova et al. 2014), "natural" $\mathrm{CD}^{+}$Th17 cells (Marks et al. 2009), and natural killer T (NKT) cells (Kronenberg 2005). All IL-17-producing cells share a common dependence on IL-23 and on the transcription factor Ror $\gamma$ t, and express the chemokine receptor CCR6 (Cua and Tato 2010). In addition, given their positioning at barrier sites and their fast responsiveness, these innate-like cells constitute important early sources of IL-17 during infection and tissue damage. Recent reports have also proposed the expression of IL-17A by myeloid cells, including macrophages, neutrophils, and mast cells (Hoshino et al. 2008; Cua and Tato 2010; Li 


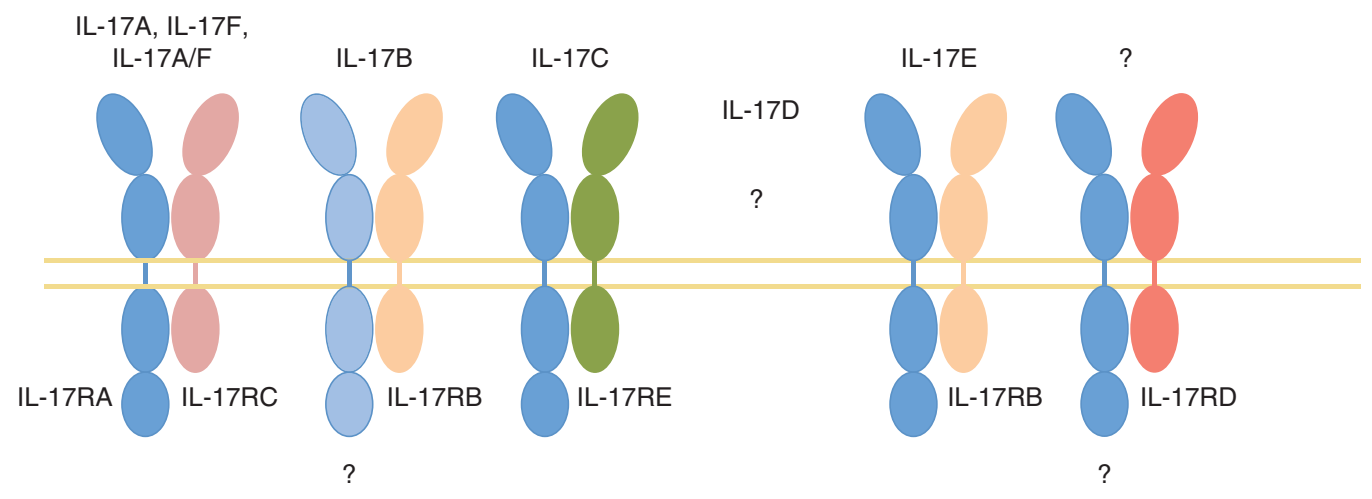

Figure 1. Interleukin 17 (IL-17) family cytokines and their receptors. Most IL-17 family cytokines signal via a heterodimeric receptor composed of IL-17RA and a second chain that varies depending on ligand, as indicated. Despite advances in the characterization of receptor-ligand interactions, several questions remain. Namely, a role for IL-17RA in IL-17B signaling has not been fully shown. In addition, the receptor for IL-17D, as well as the ligand for IL-17RD, remain unknown.

et al. 2010). However, these findings remain controversial, especially given the low levels of IL-17 detected in these cells and their propensity for phagocytosis, which might internalize IL-17 found in the environment. Indeed, a recent article showed that mast cells can take up IL-17A from the extracellular environment via receptor-mediated endocytosis and subsequently release it to promote inflammation (Noordenbos et al. 2016). Similarly, neutrophils and mast cells have been proposed to release IL17 via extracellular traps (Lin et al. 2011).

\section{IL-17E (IL-25)}

IL-17E, also known as IL-25, was discovered through a bioinformatics search for proteins homologous to IL-17A (Lee et al. 2001). At the protein level, IL-17E bears $16 \%-20 \%$ sequence similarity to IL-17A, B, and C. IL-17E derives from both hematopoietic and nonhematopoietic cells (Lee et al. 2001). In mice, IL$17 \mathrm{E}$ is expressed by innate immune cells such as mast cells and alveolar macrophages in response to allergic stimuli (Morita et al. 2015). This also seems to be true in humans, as blood eosinophils and basophils from normal and allergic subjects expressed IL-17E messenger RNA (mRNA), which was further boosted following IL-5 treatment (Wang et al. 2007). In addition, tissue stromal cells can express IL-17E. Human lung epithelial cells and murine primary type II alveolar epithelial cells express IL-17E following challenge with Aspergillus oryzae, ragweed allergens, and allergen proteases (Angkasekwinai et al. 2007; Kouzaki et al. 2013). Concordantly, IL-17E was detected at higher levels via immunohistochemistry (IHC) in the bronchial mucosa of asthmatics (Corrigan et al. 2011). The triggers for IL-17E production in many of these cells remains an active area of investigation.

IL-17E is a pleiotropic cytokine, acting on stromal, innate immune, and adaptive immune cells to orchestrate Th2-type inflammation. Consistent with the association of dysregulated Th2 responses with the development of allergy, IL-17E production is linked to the severity of chronic allergic conditions (Cheng et al. 2014). Thus, IL-17E-induced inflammation can be distinguished from IL-17A- and IL-17F-induced inflammation through the nature of the immune infiltrate, which mostly consists of eosinophils for the former and neutrophils for the latter (Morita et al. 2015). However, IL-17E expression can be advantageous in some situations, as IL-17E can inhibit Th17 development through the induction of IL-13 by dendritic cells (DCs) and by inhibiting macrophage-derived IL-23 production (Kleinschek et al. 2007). In addition, IL-17E delivery ameliorates autoim- 
mune diabetes in animal models (Emamaullee et al. 2009; Saadoun et al. 2011). IL-17E, therefore, seems to be an atypical IL-17 family member, both in terms of low sequence homology and different biological actions.

\section{IL-17C}

IL-17C was identified during the search for IL17A-related cytokines ( $\mathrm{Li}$ et al. 2000). IL-17C is mainly expressed by epithelial cells following stimulation with TLR2 and TLR5 ligands or with the proinflammatory cytokines IL- $1 \beta$ and tumor necrosis factor $\alpha$ (TNF- $\alpha)$ (RamirezCarrozzi et al. 2011). Its expression has been reported to be induced in $\mathrm{CD} 4^{+} \mathrm{T}$ cells, dendritic cells, and macrophages in inflamed tissues (Li et al. 2000; Hwang and Kim 2005). IL-17C has been suggested to act via a heterodimeric receptor composed of IL-17RA and IL-17RE, mediating a seemingly overlapping function to that of IL-17A and IL-17F (Ramirez-Carrozzi et al. 2011). Indeed, intranasal delivery of IL-17C-expressing adenovirus triggers neutrophilia and drives the expression of a set of proinflammatory molecules that overlaps considerably with IL-17A-dependent target genes (Hurst et al. 2002). Its role in mediating inflammation in several inflammatory and infection settings is just beginning to be unraveled.

\section{IL-17B and IL-17D}

IL-17B and D were also found through a search for IL-17A homologs ( Li et al. 2000; Starnes et al. 2002). IL-17B is expressed at the transcriptional level in many cell types, including chondrocytes, neurons, intestinal epithelial cells, and breast cancer cells. Similar to IL-17E, IL-17B can bind to IL-17RB, albeit with a lower affinity (Chang and Dong 2011). However, its function in the context of these cells is still enigmatic. IL-17D mRNA is detected in various tissues, including brain, heart, lung, pancreas, skeletal muscle, and adipose tissue (Starnes et al. 2002). In the immune system, expression seems to be restricted to naïve $\mathrm{CD}^{+}{ }^{+} \mathrm{T}$ cells and B cells. IL-17D most closely resembles IL-17B, with which it shares $27 \%$ homology. Its carboxy-terminal motif is absent in other IL-17 family members (Starnes et al. 2002). To date, its receptor remains unknown.

\section{IL-17 CYTOKINE SIGNALING AND REGULATION}

Most IL-17 family members characterized to date mediate signaling through heterodimeric receptors composed of IL-17RA and a subunit that confers ligand or signaling specificity. IL17RA is widely expressed among cells of both hematopoietic and nonhematopoietic compartments (Yao et al. 1995; Ishigame et al. 2009). Other IL-17R family receptors generally exhibit expression more restricted to specific cell types, which helps explain the target cell specificity of different ligands. This situation is analogous to signaling by IL- 6 or $\beta c$ family cytokines, which use the common gp130 subunit or the common $\beta$ subunit for signaling (Ozaki and Leonard 2002; Hercus et al. 2013). The existence of conserved mechanisms of receptor binding in the IL-17 family is reinforced by crystallographic analyses of IL-17RA in complex with IL-17A and IL-17F. These analyses revealed the acquisition of a similar conformation by the receptor on cytokine binding, and the requirement for the same amino acid residues for receptor-ligand interactions (Liu et al. 2013). Stoichiometry of the receptor complex seems to be dimeric. The lack of further receptor chains may be explained by the induction of conformational changes in the receptors on cytokine binding, which disfavor binding to a second homotypic receptor chain (Liu et al. 2013).

Signaling pathways downstream of IL-17 cytokine family members are beginning to be unraveled, with IL-17A-targeted signaling mechanisms having been most thoroughly studied. In this section, we will focus on current knowledge regarding the molecular actions downstream of IL-17A, and point out commonalities, divergences, and gaps in our understanding of IL-17 family cytokines.

IL-17A, IL-17F, and IL-17A/F

IL-17A and IL-17F signal through the IL-17RA/ $\mathrm{RC}$ heterodimer, evidenced by a complete loss 
of responsiveness in $1117 \mathrm{ra}^{-/-}$and $I l 17 \mathrm{rc}^{-/-}$ mice or cell lines derived from them (Gaffen 2009). Importantly, this receptor can bind to three different covalent cytokine dimers: IL17A homodimers, IL-17F homodimers, or IL$17 \mathrm{~A} / \mathrm{F}$ heterodimers, albeit with varying affinities (Wright et al. 2007). IL-17RA has a 100-fold weaker affinity for IL-17F and an intermediate affinity for the IL-17A/F heterodimer and bears weaker affinity for IL-17B, C, D, and E. Conversely, IL-17RC has a higher affinity for IL-17F than for IL-17A (Kuestner et al. 2007). Overall, IL-17A signaling induces stronger responses than IL-17F (10-30 times more potent, as assessed by downstream gene induction), which may explain its dominant role in driving autoimmunity (Zrioual et al. 2009). Receptor expression patterns also differ between the two chains, with IL-17RA being expressed more highly in the immune compartment, and IL17RC expression being largely restricted to nonimmune cells (Kuestner et al. 2007; Ishigame et al. 2009). Whether varying expression patterns coupled with the different affinity of each receptor chain for IL-17A or IL-17F underlies their diverging biological functions remains an open question.

Detailed sequence analysis of IL-17R family members revealed the presence of a conserved intracellular subdomain with homology to TollIL-1R (TIR) domains, which are essential for signaling downstream of the IL-1 receptor and Toll-like receptors (TLRs). These motifs share sequence homology with boxes 1 and 2 of the TIR domain, but lack box 3 . Interestingly, this motif was discovered in "similar expression to fibroblast (SEF) growth factor" proteins (an IL17RD ortholog) from zebrafish and chicken and hence became known as the SEFIR domain (Novatchkova et al. 2003). On cytokine ligation, the IL-17 receptor complex is thought to undergo a conformational change enabling the establishment of homotypic interactions between the SEFIR domains of the receptor and the signaling adaptor Act1 (Qian et al. 2007). Act1, also known as CIKS (connection to IкB kinase and stress-activated protein kinases), is an adapter required for all known downstream IL-17A signaling pathways. The canonical pathway re- lies on the E3 ligase activity of Act1, which mediates Lys63-linked ubiquitylation of TRAF6 (Schwandner et al. 2000). This event leads to activation of the canonical nuclear factor $\kappa \mathrm{B}$ $(\mathrm{NF}-\mathrm{\kappa B})$ and mitogen-activated protein kinase (MAPK) pathways, which include extracellular signal-regulated kinase (ERK), p38, and c-Jun amino-terminal kinase (JNK), as well as the CCAAT-enhancer-binding proteins (C/EBPs) pathway (Yao et al. 1995; Ruddy et al. 2004). Together, these transcription factors drive transcriptional activation of IL-17A target genes, which play key roles in inflammation.

In contrast, a second, noncanonical pathway is elicited by IL-17A, which leads to the stabilization of mRNA transcripts, particularly those encoding for intrinsically unstable targets such as cytokines and chemokines. This mRNA stabilization pathway is dependent on IкB kinase (IKKi) and TBK1-mediated phosphorylation of Act1 (Bulek et al. 2011; Qu et al. 2012). TRAF2 and TRAF5 are thereby recruited to the receptor complex, which results in the recruitment of molecules that control mRNA turnover (Sun et al. 2011). In particular, TRAF2 and TRAF5 can sequester the RNA-destabilizing factor ASF/SF2 and recruit the mRNA-stabilizing factor HuR, enhancing the half-life of various mRNAs (Sun et al. 2011; Herjan et al. 2013). In addition, Act1 is reported to interact with Hsp90 to activate IL-17 activity (Wang et al. 2013). A psoriasis-associated genetic variant in Actl carrying the D10N mutation abrogates this interaction (Ellinghaus et al. 2010; Genetic Analysis of Psoriasis Consortium \& the Wellcome Trust Case Control Consortium 2 et al. 2010; Hüffmeier et al. 2010). Together, IL-17-mediated events at both the transcriptional and posttranscriptional levels enhance production of genes that underlie its functions, including cytokines and chemokines, antimicrobial peptides (AMPs), acute phase proteins, and other inflammatory effectors (Onishi and Gaffen 2010). IL-17RA/ $\mathrm{RC}$ signaling is summarized in Figure 2.

\section{IL-17E (IL-25) \\ IL-17E signals through a heterodimer of IL-17RA and IL-17RB (Rickel et al. 2008), as}




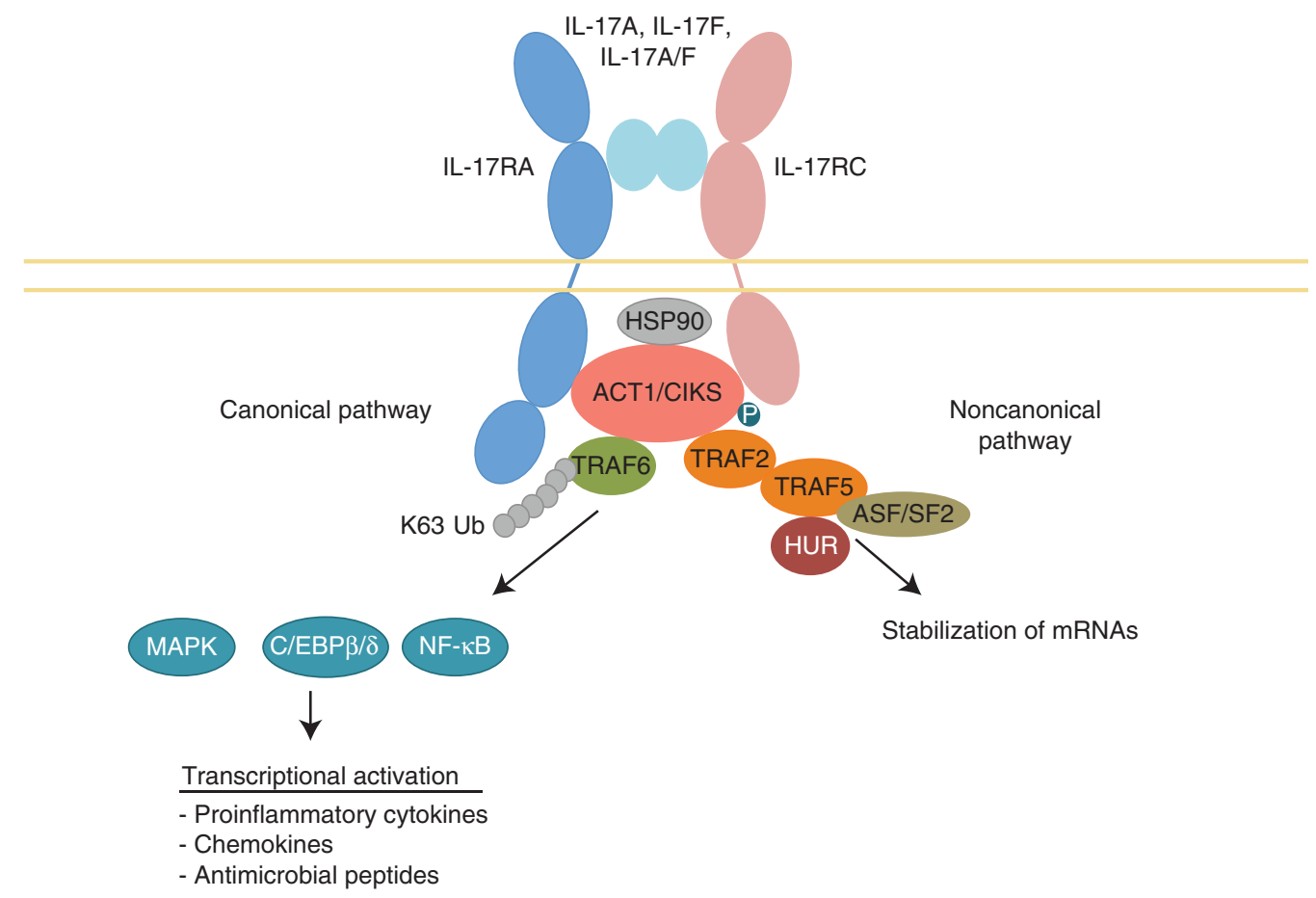

Figure 2. Interleukin (IL)-17RA/RC signaling pathways. IL-17A/IL-17F/IL-17A/F binding to the receptor complex enables homotypic interactions between the SEF/IL-17R (SEFIR) domains in the receptor and in the adapter Act1/CIKS. The canonical IL-17 signaling pathway initiates signaling through Actl-induced K63linked ubiquitylation of TRAF6, thereby activating the mitogen-activated protein kinase (MAPK), CCAATenhancer-binding protein $\beta(\mathrm{C} / \mathrm{EBP} \beta)$, and nuclear factor $\kappa \mathrm{B}(\mathrm{NF}-\kappa \mathrm{B})$ pathways. This triggers transcriptional activation of downstream target genes, including proinflammatory cytokines, chemokines, and antimicrobial peptides. In turn, noncanonical signaling relies on Act 1 phosphorylation at amino acid 311 . This recruits TRAF2 and TRAF5, which sequesters the messenger RNA (mRNA)-destabilizing factor ASF/SF2 and recruits the mRNA-stabilizing factor HuR. Together, these two pathways mediate the proinflammatory functions of IL17A, IL-17F, and IL-17A/F.

summarized in Figure 3. Unlike the relatively stromal-restricted activity of IL-17A and IL17F, IL-17E acts mainly on immune cells, including Th2, Th9, and NKT cells. IL-17E induces the production of classical type 2 cytokines, such as IL-4, IL-5, IL-9, and IL-13, in a Gata3-, c-MAF-, and JunB-dependent fashion (Wang et al. 2007). IL-17RB is also expressed on monocytes, certain populations of type 2 innate lymphocytes such as nuocytes, non- $\mathrm{T} /$ non- $\mathrm{B}$ cells, multipotent progenitor type 2 cells, and innate type 2 helper cells (Dolgachev et al. 2009; Moro et al. 2010; Neill et al. 2010; Price et al. 2010). In addition, stromal cells such as intestinal and pulmonary epithelial cells also respond to IL-17E. Similar to IL-17A/F signaling, IL-
17RB interacts with Act1 via homotypic SEFIR interactions (Claudio et al. 2009; Swaidani et al. 2009). Act1 recruits TRAF6, enabling NF- $\kappa B$ activation (Maezawa et al. 2006). However, the pathways diverge in that IL-17RB can recruit TRAF4 via Act1, leading to the further recruitment of the E3 ligase SMURF2 (Zepp et al. 2015). This leads to the ubiquitylation and subsequent degradation of the IL-17RB inhibitor DAZAP2, consequently reinforcing IL-17E-mediated signaling (Zepp et al. 2015). Further, IL$17 \mathrm{E}$ is reported to activate STAT5 in an Act1independent manner, which further potentiates a Th2 response (Wu et al. 2015b). The precise stoichiometry of the receptor required for signaling via IL-17E is currently unclear, as there 


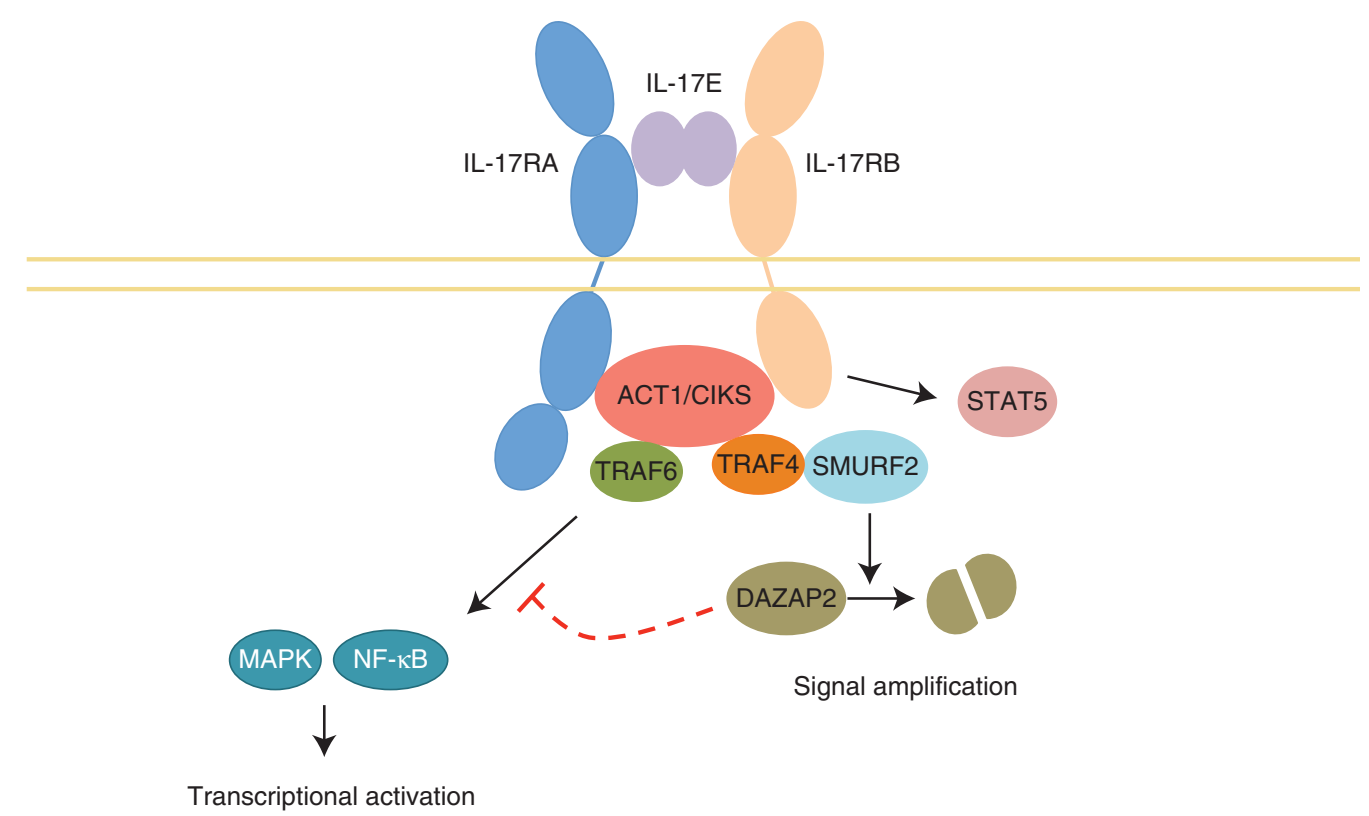

Figure 3. Interleukin (IL)-17RA/RB signaling. On IL-17E binding to its receptor, homotypic interactions between the SEF/IL-17R (SEFIR) domains in the receptor and in the adapter Act1/CIKS are established. This leads to the recruitment of TRAF6, activating the mitogen-activated protein kinase (MAPK) and nuclear factor $\kappa \mathrm{B}(\mathrm{NF}-\kappa \mathrm{B})$ signaling pathways. In turn, Act1 can recruit TRAF4, which activates the E3 ligase SMURF2. This leads to the ubiquitylation and subsequent degradation of the inhibitor DAZAP2, amplifying IL-17Emediated signaling. In addition, IL-17RB can elicit STAT5 activation in an Act1-independent manner.

are reports of IL-17E being unable to bind IL17RA in vitro (Hymowitz et al. 2001). Whether the nature of the receptor varies depending on the cell type is another area of inquiry.

\section{IL-17B, C, and D}

Our current understanding of signaling downstream of IL-17 family members other than IL$17 \mathrm{~A}, \mathrm{~F}$, and $\mathrm{E}$ remains very limited. IL-17B has been shown to induce proinflammatory cytokine secretion by the THP-1 acute monocytic leukemic cell line, and to enhance inflammation, survival, and metastasis in breast and pancreatic cancer (Huang et al. 2014; Wu et al. 2015a). IL-17RB engagement in these cells recruited the Act1-TRAF6-TAK1 complex to the receptor (Wu et al. 2015a). Interestingly, IL-17B and IL-17E seem to present antagonic activities, despite reportedly binding to the same receptor (Reynolds et al. 2015). IL-17C has been reported to signal via a heterodimeric IL-17RA/RE complex (Ramirez-Carrozzi et al. 2011). Expression of IL-17RE is restricted to epithelial cells, specialized epithelial cells like keratinocytes and Th17 cells (reviewed in Song et al. 2016). In line with other proinflammatory cytokines in the family, IL-17C signaling activates the NF- $\kappa B$ and MAPK pathways (Song et al. 2011). Similar to other cytokines in the family, IL-17C signaling also seems to be dependent on Act1, and Song et al. have recently reported that IL-17RE associates with Act1 (Song et al. 2016). As noted above, the action of IL-17D, its receptor, and the signaling mechanisms it elicits remain obscure.

\section{Regulation of IL-17 Family Cytokines}

Given its central role in inflammation, numerous mechanisms have evolved to restrict the IL17A signaling pathway, presumably to curtail bystander inflammation. For example, TRAF3 and TRAF4 interfere with early events in IL-17A 
signaling by competing with Act1 or TRAF6 for IL-17RA binding (Zhu et al. 2010; Zepp et al. 2012). The deubiquitinase A20 is induced downstream of IL-17A and dampens the activation of NF- $\kappa$ B and MAPK pathways by removal of K63-linked ubiquitin chains on TRAF6 (Garg et al. 2013). Thus, A20 serves as a feedback regulator of the IL-17 pathway, analogous to its effect for TNF- $\alpha$ and IL-1 signaling as well (He and Ting 2002; Duong et al. 2015; Luo et al. 2015). Similarly, the deubiquitinase USP25 acts on TRAF5 and TRAF6, suppressing IL-17A signaling (Johnston et al. 2013). GSK-3 $\beta$-mediated phosphorylation of the transcription factor C/EBP $\beta$ inhibits IL-17 target gene expression (Shen et al. 2009). Genome-wide association study (GWAS) analysis of psoriasis has revealed genetic associations with known regulators of immune signaling, including TNFAIP3 (A20), TNIP1 (ABIN-1, NAF1), and NFKBIA (ІкB $\alpha$ ) (Harden et al. 2015). Importantly, ABIN-1 was recently shown to regulate IL-17A signaling in keratinocytes. Correspondingly, Tnip1-deficient mice develop cutaneous inflammation with psoriasiform characteristics, linking findings in this mouse model to the enhanced susceptibility to psoriasis of individuals with TNIP1 single-nucleotide polymorphisms (SNPs) (Ippagunta et al. 2016). Finally, the endoribonuclease MCPIP1 (also known as Regnase-1, encoded by ZC3H12A) limits IL-17 signaling through the degradation of IL-17-driven genes, including Il6, Nfkbiz, and Ill7ra and Ill7rc (Sonder et al. 2011; Garg et al. 2015; Somma et al. 2015). To date, 11 nonsynonymous SNPs have been described for the $Z C 3 H 12 A$ gene, but so far none are associated with human disease (Cifuentes et al. 2010).

With an emerging role in inflammatory diseases (Johnston et al. 2013), IL-17C may similarly be subject to robust control mechanisms, although little is currently known about this issue. We recently showed that the action of MCPIP1 can also curb IL-17C-mediated inflammation in murine keratinocytes both in vitro and in vivo, thereby limiting skin inflammation in the imiquimod-driven psoriasis model (Monin et al. 2017). Given the high degree of conservation across signaling pathways in the
IL-17 family of cytokines, it is tempting to speculate that other members of the IL-17 will share common regulatory mechanisms.

\section{IL-17 FAMILY CYTOKINES IN HOST PROTECTION AND INFLAMMATION}

\section{IL-17A, F, and A/F in Infection}

IL-17A and IL-17F evolved to protect from infection, and it is now clear that they orchestrate protective responses against infections at mucosal and epithelial surfaces, including the intestine, skin, lung, and oral cavity. Their central role in mediating protective immunity relies on the induction of molecules that stimulate epithelial barrier function. Signaling downstream of IL-17RA/RC elicits the expression of AMPs, including $\beta$-defensins, S100 proteins, and lipocalin-2 ([Lcn2], also known as $24 \mathrm{p} 3$ or NGAL) (Yang et al. 1999). Lcn2 competes with bacterial siderophores for acquisition of free iron and thus limits bacterial growth (Yang et al. 2002). In addition, IL-17A and IL$17 \mathrm{~F}$ induce a proinflammatory milieu with enhanced cytokine and chemokine, and matrix metalloproteinase (MMP) production. These factors mediate the activation and recruitment of immune cells to the site of infection, promoting a potent immune response to the invading pathogen. One of the hallmarks of IL-17A-driven inflammation is neutrophil accumulation. Indeed, induction of granulocyte colony-stimulating factor (G-CSF) regulates neutrophil production, whereas chemokines such as CXCL1, CXCL5, and CCL2 stimulate neutrophil chemotaxis (Shen et al. 2005). In addition, IL-17 induces CCL20, which recruits CCR6expressing cells such as Th17 and ILC3s (Acosta-Rodriguez et al. 2007). In this manner, IL-17A and to a lesser extent IL-17F regulate the coordinated action of stromal, innate, and adaptive immune cells.

The central role of IL-17A and IL-17F in protective immunity against infections is highlighted by the increased susceptibility of IL-17A or IL-17F-deficient mice to pathogens. For example, IL-17RA - / - mice are unable to control lung infection with Klebsiella pneumoniae 
(Ye et al. 2001). In addition, IL-17A stimulates macrophage-derived IL-12, which is required to promote protective Th1 responses against pulmonary infection with Francisella tularensis live vaccine strain (Lin et al. 2009). Furthermore, IL17 levels are elevated during acute lung infection with Pseudomonas aeruginosa, which contributes to neutrophil recruitment and bacterial containment (Liu et al. 2011; Dubin et al. 2012). Similarly, a deficiency in IL-17 or the IL-17promoting cytokine IL-23 renders mice more susceptible to Citrobacter rodentium intestinal infection (Mangan et al. 2006), as well as to a number of other bacterial pathogens (reviewed in Curtis and Way 2009; Manni et al. 2014).

Candida albicans is a commensal fungal organism in about $70 \%$ of healthy individuals, residing in the skin, mouth, gastrointestinal tract, and vagina without causing disease. However, following loss of immune control mechanisms, C. albicans can become an opportunistic pathogen. Chronic mucocutaneous candidiasis (CMC) can ensue in individuals with primary and acquired immunodeficiencies, leading to oropharyngeal candidiasis ([OPC] or thrush), or to cutaneous lesions. Importantly, defects in the IL-17/IL-23 axis render the host exquisitely susceptible to CMC, highlighting the importance of this pathway in controlling $C$. albicans infections. Genetic variants in IL-12R $\beta 1$ and STAT3, which compromise IL-23 signaling, have also been associated with diminished Th17 responses in humans and accordingly to CMC (Milner and Holland 2013).

IL-17A is required for control of $C$. albicans OPC infection in mice, although IL-17F and IL-17AF may also contribute to protection (Whibley et al. 2016). Notably, a mutation in the $I L 17 F$ gene was recently reported in a family with CMC (Puel et al. 2011). This point mutation at position 65 in the polypeptide chain leads to the production of a dominant-negative variant, which abrogates IL-17F and IL-17A/ IL-17F heterodimer signaling. Likewise, mutations in IL-17RA, IL-17RC, and Act1 lead to CMC in humans. Mutations in the AIRE gene (autoimmune regulator) lead to the development of the multiorgan autoimmune disease APECED (autoimmune polyendocrinopathy candidiasis ectodermal dystrophy). One of the main manifestations of APECED is an enhanced susceptibility to CMC (Milner and Holland 2013). Interestingly, compromised negative selection in the thymus because of AIRE deficiency leads to the development of neutralizing autoantibodies against IL-17A, IL-17F, and IL-22 (Puel et al. 2010). Importantly, the dependence of the host on IL-17 for containment of Candida infections is dependent on colonization route and tissue. For instance, vulvovaginal candidiasis is associated with alterations in other host factors, such as $\mathrm{pH}$ and microbial flora composition. In turn, control of systemic candidiasis seems to be more reliant on Th1 and natural killer (NK) cell responses (Conti and Gaffen 2015).

Staphylococcus aureus dermatitis has been reported in patients with ACT1 or IL17RA null variants (Puel et al. 2011; Boisson et al. 2013). In line with a role for IL-17 in S. aureus control, Il17ra-deficient mice exhibit an increased susceptibility to cutaneous $S$. aureus infection (Cho et al. 2010; Chan et al. 2015). Given the emergence in recent years of methicillinresistant $S$. aureus (MRSA) strains, harnessing the IL-17 axis in vaccination strategies may be of prophylactic promise.

\section{IL-17A, F, and A/F in Chronic Skin Inflammatory and Autoimmune Diseases}

Up-regulation of inflammatory and tissue-remodeling molecules can lead to tissue damage if IL-17 activity is left uncontrolled. Indeed, IL17A and related cytokines are up-regulated in numerous autoimmune conditions, including psoriasis, rheumatoid arthritis (RA), multiple sclerosis, scleroderma, and lupus, among others. Similarly, GWAS studies have associated SNPs in genes of the IL-17 pathway with autoimmunity. A number of reviews have recently addressed the role of IL-17 in other autoimmune conditions (Iwakura et al. 2011; Song et al. 2016). We will focus here on the role of IL-17A and IL-17F in driving cutaneous inflammation (Table 1).

Psoriasis is a chronic inflammatory skin condition characterized by epidermal hyperplasia, affecting $2 \%-3 \%$ of the world's population. 
L. Monin and S.L. Gaffen

Table 1. Cytokines and receptors driving cutaneous inflammation

\begin{tabular}{llll}
\hline Cytokine & \multicolumn{1}{c}{ Receptor } & \multicolumn{1}{c}{ Infection } & \multicolumn{1}{c}{ Skin inflammatory phenotype(s) } \\
\hline IL-17A and IL-17F & IL-17RA/RC & $\begin{array}{l}\text { Candida albicans, } \\
\text { Staphylococcus aureus }\end{array}$ & $\begin{array}{c}\text { Psoriasis, atopic dermatitis, } \\
\text { skin cancer }\end{array}$ \\
IL-17B & IL-17RB/? & Undefined & Undefined \\
IL-17C & IL-17RA/RE & S. aureus & Psoriasis \\
IL-17D & Undefined & Undefined & Undefined \\
IL-17E (IL-25) & IL-17RA/RB & Undefined & Psoriasis, atopic dermatitis \\
\hline
\end{tabular}

IL, Interleukin.

One of the hallmarks of disease is neutrophilic infiltration and formation of neutrophil microabscesses (Nestle et al. 2009). Elevated IL-17A and Th17-related cytokines such as IL-22 and IL-23 are found in human psoriasis skin lesions (Wilson et al. 2007; Johansen et al. 2009; Johnston et al. 2013). In addition, IL-17A can directly act on human keratinocytes stimulated to upregulate AMPs and neutrophil-attracting chemokines (Liang et al. 2006; Nograles et al. 2008). Consistently, GWAS studies have identified psoriasis-associated variants in genes participating in Th17 differentiation and IL-17A signaling, such as IL23R and TRAF3IP2 (encoding Act1) (Cargill et al. 2007; Ellinghaus et al. 2010; Hüffmeier et al. 2010; Sonder et al. 2012; Tsoi et al. 2012). Mouse preclinical models of psoriasis have confirmed a role for IL-17 family cytokines in mediating disease. In the imiquimod-driven dermatitis model (driven by a TLR7 agonist), IL-17RA-deficient mice show dramatically diminished skin involvement (van der Fits et al. 2009). Interestingly, IL-17 signaling plays a dual role during imiquimod-driven psoriasis, its role varying by cell type. Mice deficient in IL-17 signaling in keratinocytes present dampened keratinocyte proliferation and neutrophilic microabscess formation. In turn, Act1 deficiency in skin fibroblasts limits the recruitment of IL-17producing cells, thereby controlling the amplification of skin inflammation (Ha et al. 2014). Interestingly, intradermal injection of IL-22 or IL-23 into mouse ear also elicits the development of psoriasis-like disease, indicating that other cytokines in the IL-23/IL-17 axis can initiate disease (Song et al. 2016). The importance of IL-17A-mediated inflammation in psoriasis has been more recently highlighted by the clinical success of biologic drugs, including IL17A-blocking antibodies secukinumab and ixekizumab and the IL-17RA-targeting antibody brodalumab (Leonardi et al. 2012; Langley et al. 2014; Baeten et al. 2015; Durham et al. 2015; Sanford and McKeage 2015).

Atopic dermatitis affects $10 \%-20 \%$ of children and $1 \%-3 \%$ of adults in the Western world (Schultz Larsen 1996), and is characterized by chronic skin inflammation because of exacerbated responses to environmental antigens. The IL-17 axis has been reported to participate in allergic skin reactions, including atopic dermatitis and contact dermatitis. Serum levels of IL-17A and F are increased in children with atopic dermatitis and positively correlated with disease severity (Leonardi et al. 2015). Expression of IL-17A at the mRNA level is increased in the skin of patients with nickel allergy (Albanesi et al. 1999). In addition, increased Th17 cell infiltration was detected in a mouse model of contact dermatitis, and IL-17A-deficient mice displayed reduced pathology (Nakae et al. 2002). Whether the enhancement of IL-17 responses is a driver of pathology or reflects the immune efforts to limit colonization of skin lesions by bacteria remains an open question.

Strikingly, IL-17 signaling has been associated with the promotion of skin cancer development during chemical carcinogenesis in mouse models. Indeed, IL-17 or IL-17RA-deficient mice show considerably diminished incidence of DMBA/TPA-induced skin tumors (Wang et al. 2010; He et al. 2012). This protumorigenic effect of IL-17 is thought to occur via the promotion of epithelial proliferation and the antiapoptotic effect of STAT-3, which may be downstream of IL-17-induced genes such as 
IL-6. Importantly, IL-17RA blocking in mice with established tumors blocked further tumor progression (He et al. 2012). Thus, IL-17A blockade may be useful for controlling at least some cancers.

\section{IL-17B}

IL-17B is expressed by neutrophils in the synovial tissue of RA patients (Kouri et al. 2014). Treatment of human fibroblasts with IL-17B synergized with TNF- $\alpha$ to induce G-CSF and IL-6 (Kouri et al. 2014). Intriguingly, IL-17B is expressed in limb buds during mouse embryonic development, suggesting a role in chondrogenesis and osteogenesis that may be dysregulated in autoimmune processes affecting the joints (You et al. 2005). IL-17B, like IL-17E (IL-25), has been shown to bind to IL-17RB. IL17B can oppose IL-25-driven inflammation, and has been shown to play an antagonistic role. In a dextran sulphate sodium (DSS)-driven colitis mouse model, IL-25 administration exacerbated colonic damage (McHenga et al. 2008). In contrast, in a second report, IL-25deficient mice exhibited reduced weight loss, inflammation, and tissue damage (Reynolds et al. 2015). These discrepant findings may result from differences in microbiome composition between the two studies. Interestingly, IL-17B-deficient mice developed increased susceptibility to DSS colitis, with enhanced weight loss, proinflammatory cytokine production, and colonic tissue destruction (Reynolds et al. 2015). Similarly, IL-17B and IL-25 play opposing roles in the context of Citrobacter rodentium infection and ovalbumin (OVA)-induced lung inflammation (Reynolds et al. 2015). In vitro, cotreatment of primary colonic epithelial cells with IL-17B diminished IL-25-, but not IL-17Adriven IL-6 production. IL-17B remains among the most obscure of all IL-17 family members, with a role in skin immunity and pathology yet to be ascribed. The described antagonism to IL-25 function is interesting in this context, particularly given the association between IL25 expression and skin atopy. The potential role of IL-17B in skin immunity and pathology should therefore be explored.
IL-17C

As noted above, IL-17C induces a similar pattern of gene expression to IL-17A, which poses the question of functional redundancy. However, despite the overlap in target gene induction, IL-17C-deficient mice do not exhibit a compromised ability to control oral, dermal, or disseminated candidiasis, in contrast to IL-17RA-deficient mice (Conti et al. 2015). In addition, the IL-17RA-dependent gene signature associated with immunity against $C$. albicans was unchanged in IL-17C-deficient mice. Concordantly, IL-17RE deficiency did not lead to enhanced susceptibility to candidiasis. Interestingly, IL17C can be induced in keratinocytes infected with $S$. aureus via a NOD2-dependent mechanism. Using this in vitro system, suppression of IL-17C expression rendered keratinocytes slightly more permissive to $S$. aureus survival (Roth et al. 2014). Thus, IL-17C may contribute to the control of infections, potentially through the activation of common mechanisms with IL$17 \mathrm{~A}$ and $\mathrm{F}$.

A common feature for IL-17 family cytokines or indeed all inflammatory stimuli is their propensity to promote protective immunity while simultaneously exacerbating tissue damage. IL-17C is the most highly expressed IL-17 family member in psoriatic lesions (Wilson et al. 2007; Johansen et al. 2009; Johnston et al. 2013), and drives the expression of AMPs, proinflammatory cytokines, and neutrophil-attracting chemokines in keratinocytes (Liang et al. 2006; Nograles et al. 2008). Consistent with a role in mediating cutaneous pathology, intradermal delivery of recombinant IL-17C into mouse ears led to epidermal thickening and neutrophil recruitment, whereas IL-17Cdeficient mice developed less skin inflammation on imiquimod treatment (Ramirez-Carrozzi et al. 2011). In line with these findings, keratinocyte-specific IL-17C transgenic mice develop spontaneous psoriasiform dermatitis with epidermal hyperplasia, increased leukocytosis, and overexpression of proinflammatory cytokines (Johnston et al. 2013). Consistent with manifestations in human psoriasis, these mice display an enhanced proclivity toward thrombotic 
arterial occlusion, indicating the potential systemic effects of a skin inflammatory process (Golden et al. 2015). Therefore, IL-17C is clearly a driver of psoriasis and could be a safer target for blockade because its role in immunity to infection, at least in mice, appears to be less central (Conti et al. 2015).

\section{IL-17D}

As mentioned, the orphan cytokine IL-17D is poorly understood, with reports showing that this cytokine can induce IL-6, IL-8, and GMCSF expression in endothelial cells (Starnes et al. 2002) and IL-6 and IL-8 in chicken fibroblasts (Hong et al. 2008). Interestingly, the stress-sensing protein NRF2 induces IL-17D expression in cancer cells. IL-17D-deficient mice displayed increased tumor growth when compared to wild-type mice (Saddawi-Konefka et al. 2016). Recent studies have also linked IL$17 \mathrm{D}$ to the recruitment of $\mathrm{NK}$ cells into the tumor microenvironment and subsequent activation (O’Sullivan et al. 2014; Saddawi-Konefka et al. 2014). Indeed, IL-17D plays a dual role in promoting human NK cell cytotoxicity and inducing NK-recruiting MCP-1 by tumor endothelial cells, thus placing this cytokine in a central role in tumor surveillance (O'Sullivan et al. 2014). The potential involvement of IL-17D in cutaneous surveillance mechanisms remains an open question.

\section{IL-17E}

IL-17E is an interesting example of an IL-17family cytokine that possesses a divergent function to its founding member IL-17A. Like IL17A, IL-17E can activate NF- $\kappa$ B and induce the production of IL-8. In addition, transgenic mice overexpressing IL-17E develop common features of IL-17A-driven inflammation, including neutrophilia and elevated circulating G-CSF (Pan et al. 2001). However, IL-17E functions mainly to stimulate Th2 responses, promoting Th2 cytokine secretion, class switch recombination to $\operatorname{IgE}$, IgG1, and $\operatorname{IgA}$, and the recruitment and activation of eosinophils in both mice and humans. Indeed, IL-17E transgenic mice present with eosinophilia, increased $\operatorname{IgE}$ and IgG1, and elevated serum IL-5 and IL-13 (Pan et al. 2001). Given its role in promoting Th2mediated immunity, IL-17E plays a central role in protection against helminth infection (Fallon et al. 2006; Owyang et al. 2006). In turn, IL17E mRNA expression is enhanced in the lungs of asthmatic patients (Wang et al. 2007), and IL17E delivery promotes Th2 cytokine and IgE production as well as eosinophil infiltration in a mouse model of asthma (Fort et al. 2001).

IL-17E expression has been reported in patients with several skin conditions. In particular, an SNP in the IL17E gene is positively correlated with severe forms of psoriasis in a Spanish cohort of patients (Batalla et al. 2015). However, the effect of this polymorphism on IL-17E expression and/or function remains unknown. Atopic dermatitis often presents in association with mutations in the gene encoding filaggrin (Palmer et al. 2006; Weidinger et al. 2006; Barker et al. 2007). IL-25 was overexpressed in the epidermis of atopic dermatitis patients and in corresponding mouse models (Hvid et al. 2011; Aktar et al. 2015). In cultured keratinocytes, IL-25 treatment inhibited the expression of filaggrin, which may account for the loss of skin barrier function associated with atopic dermatitis (Hvid et al. 2011). In addition, IL-25 can mediate the recruitment of "type 2" cytokineproducing ILC2s in atopic dermatitis (Salimi et al. 2013). Therefore, IL-25 plays a dual role in promoting atopic dermatitis via stimulation of type 2 responses and through its direct action on keratinocytes.

\section{CONCLUDING REMARKS}

The IL-17 family of cytokines plays a central part in the induction of inflammation to limit numerous pathogenic insults. Here, we have reviewed the prominent role of IL-17A in orchestrating protective responses against cutaneous bacterial and fungal infections and the emerging roles of other IL-17 family members in boosting immunity. Given the recent development of novel therapies to block IL-17A and IL17RA signals in chronic inflammatory diseases, the potential long-term consequences of such 
treatments vis-à-vis the exacerbation of fungal and extracellular bacterial infections should be examined. In that light, dissecting the commonalities and divergences in signaling pathways that drive protective versus tissue disruptive functions could provide alternative therapeutic strategies for at-risk populations. Given the pleiotropic roles of IL-17 family members, an in-depth analysis of individual cytokines' roles during infection and inflammation could provide insight into the advantages of the therapeutic alternatives that are currently under study, including IL-17A- versus IL-17RA-blocking strategies.

\section{ACKNOWLEDGMENTS}

S.L.G. is supported by the National Institutes of Health (Grants AI107825, AR062546, and DE022550). S.L.G. received research grants from Janssen and Novartis, and serves on the Scientific Advisory Board of Lycera Corporation. There are no other conflicts of interest.

\section{REFERENCES}

Acosta-Rodriguez EV, Rivino L, Geginat J, Jarrossay D, Gattorno M, Lanzavecchia A, Sallusto F, Napolitani G. 2007. Surface phenotype and antigenic specificity of human interleukin 17-producing T helper memory cells. Nat Immunol 8: 639-646.

Aggarwal S, Gurney AL. 2002. IL-17: Prototype member of an emerging cytokine family. J Leukoc Biol 71: 1-8.

Aktar MK, Kido-Nakahara M, Furue M, Nakahara T. 2015. Mutual upregulation of endothelin-1 and IL-25 in atopic dermatitis. Allergy 70: 846-854.

Albanesi C, Cavani A, Girolomoni G. 1999. IL-17 is produced by nickel-specific $\mathrm{T}$ lymphocytes and regulates ICAM-1 expression and chemokine production in human keratinocytes: Synergistic or antagonist effects with IFN- $\gamma$ and TNF- $\alpha$. J Immunol 162: 494-502.

Angkasekwinai P, Park H, Wang YH, Wang YH, Chang SH, Corry DB, Liu YJ, Zhu Z, Dong C. 2007. Interleukin 25 promotes the initiation of proallergic type 2 responses. $J$ Exp Med 204: 1509-1517.

Awasthi A, Riol-Blanco L, Jager A, Korn T, Pot C, Galileos G Bettelli E, Kuchroo VK, Oukka M. 2009. Cutting edge: IL23 receptor gfp reporter mice reveal distinct populations of IL-17-producing cells. J Immunol 182: 5904-5908.

Baeten D, Sieper J, Braun J, Baraliakos X, Dougados M, Emery P, Deodhar A, Porter B, Martin R, Andersson M, et al. 2015. Secukinumab, an Interleukin-17A inhibitor, in ankylosing spondylitis. N Engl J Med 373: 2534-2548.
Barker JN, Palmer CN, Zhao Y, Liao H, Hull PR, Lee SP, Allen MH, Meggitt SJ, Reynolds NJ, Trembath RC, et al. 2007. Null mutations in the filaggrin gene (FLG) determine major susceptibility to early-onset atopic dermatitis that persists into adulthood. J Invest Dermatol 127: $564-567$.

Batalla A, González-Lara L, González-Fernández D, Gómez J, Aranguren TF, Queiro R, Santos-Juanes J, López-Larrea C, Coto-Segura P. 2015. Association between single nucleotide polymorphisms IL17RA rs4819554 and IL17E rs79877597 and psoriasis in a Spanish cohort. J Dermatol Sci 80: $111-115$

Bettelli E, Carrier Y, Gao W, Korn T, Strom TB, Oukka M, Weiner HL, Kuchroo VK. 2006. Reciprocal developmental pathways for the generation of pathogenic effector TH17 and regulatory T cells. Nature 441: 235-238.

Boisson B, Wang C, Pedergnana V, Wu L, Cypowyj S, Rybojad M, Belkadi A, Picard C, Abel L, Fieschi C, et al. 2013. An ACT1 mutation selectively abolishes interleukin-17 responses in humans with chronic mucocutaneous candidiasis. Immunity 39: 676-686.

Bulek K, Liu C, Swaidani S, Wang L, Page RC, Gulen MF, Herjan T, Abbadi A, Qian W, Sun D, et al. 2011. The inducible kinase IKKi is required for IL-17-dependent signaling associated with neutrophilia and pulmonary inflammation. Nat Immunol 12: 844-852.

Cargill M, Schrodi SJ, Chang M, Garcia VE, Brandon R, Callis KP, Matsunami N, Ardlie KG, Civello D, Catanese JJ, et al. 2007. A large-scale genetic association study confirms IL12B and leads to the identification of IL23R as psoriasis-risk genes. Am J Hum Genet 80: 273-290.

Chan LC, Chaili S, Filler SG, Barr K, Wang H, Kupferwasser D, Edwards JEJr, Xiong YQ, Ibrahim AS, Miller LS, et al. 2015. Nonredundant roles of interleukin-17A (IL-17A) and IL-22 in murine host defense against cutaneous and hematogenous infection due to methicillin-resistant Staphylococcus aureus. Infect Immun 83: 4427-4437.

Chang SH, Dong C. 2011. Signaling of interleukin-17 family cytokines in immunity and inflammation. Cell Signal 23: 1069-1075.

Cheng D, Xue Z, Yi L, Shi H, Zhang K, Huo X, Bonser LR, Zhao J, Xu Y, Erle DJ, et al. 2014. Epithelial interleukin-25 is a key mediator in Th2-high, corticosteroid-responsive asthma. Am J Respir Crit Care Med 190: 639-648.

Cho JS, Pietras EM, Garcia NC, Ramos RI, Farzam DM, Monroe HR, Magorien JE, Blauvelt A, Kolls JK, Cheung AL, et al. 2010. IL-17 is essential for host defense against cutaneous Staphylococcus aureus infection in mice. J Clin Invest 120: 1762-1773.

Cifuentes RA, Cruz-Tapias P, Rojas-Villarraga A, Anaya JM. 2010. ZC3H12A (MCPIP1): Molecular characteristics and clinical implications. Clin Chim Acta 411: 18621868 .

Claudio E, Sønder SU, Saret S, Carvalho G, Ramalingam TR, Wynn TA, Chariot A, Garcia-Perganeda A, Leonardi A, Paun A, et al. 2009. The adaptor protein CIKS/Act1 is essential for IL-25-mediated allergic airway inflammation. J Immunol 182: 1617-1630.

Conti HR, Gaffen SL. 2015. IL-17-mediated immunity to the opportunistic fungal pathogen Candida albicans. J Immunol 195: 780-788. 
Conti HR, Whibley N, Coleman BM, Garg AV, Jaycox JR, Gaffen SL. 2015. Signaling through IL-17C/IL-17RE is dispensable for immunity to systemic, oral and cutaneous candidiasis. PLoS ONE 10: e0122807.

Corrigan CJ, Wang W, Meng Q, Fang C, Eid G, Caballero MR, Lv Z, An Y, Wang YH, Liu YJ, et al. 2011. Allergeninduced expression of IL-25 and IL-25 receptor in atopic asthmatic airways and late-phase cutaneous responses. J Allergy Clin Immunol 128: 116-124.

Cua DJ, Tato CM. 2010. Innate IL-17-producing cells: The sentinels of the immune system. Nat Rev Immunol 10: 479-489.

Cua DJ, Sherlock J, Chen Y, Murphy CA, Joyce B, Seymour B, Lucian L, To W, Kwan S, Churakova T, et al. 2003. Interleukin-23 rather than interleukin-12 is the critical cytokine for autoimmune inflammation of the brain. Nature 421: $744-748$.

Curtis MM, Way SS. 2009. Interleukin-17 in host defense against bacterial, mycobacterial and fungal pathogens. Immunology 126: 177-185.

Dolgachev V, Petersen BC, Budelsky AL, Berlin AA, Lukacs NW. 2009. Pulmonary IL-17E (IL-25) production and IL-17RB ${ }^{+}$myeloid cell-derived Th2 cytokine production are dependent upon stem cell factor-induced responses during chronic allergic pulmonary disease. J Immunol 183: $5705-5715$.

Dubin PJ, Martz A, Eisenstatt JR, Fox MD, Logar A, Kolls JK. 2012. Interleukin-23-mediated inflammation in Pseudomonas aeruginosa pulmonary infection. Infect Immun 80: $398-409$.

Duong BH, Onizawa M, Oses-Prieto JA, Advincula R, Burlingame A, Malynn BA, Ma A. 2015. A20 restricts ubiquitination of pro-interleukin- $1 \beta$ protein complexes and suppresses NLRP3 inflammasome activity. Immunity 42: 55-67.

Durham LE, Kirkham BW, Taams LS. 2015. Contribution of the IL-17 pathway to psoriasis and psoriatic arthritis. Curr Rheumatol Rep 17: 55.

Ellinghaus E, Ellinghaus D, Stuart PE, Nair RP, Debrus S, Raelson JV, Belouchi M, Fournier H, Reinhard C, Ding J, et al. 2010. Genome-wide association study identifies a psoriasis susceptibility locus at TRAF3IP2. Nat Genet 42: 991-995.

Emamaullee JA, Davis J, Merani S, Toso C, Elliott JF, Thiesen A, Shapiro AM. 2009. Inhibition of Th17 cells regulates autoimmune diabetes in NOD mice. Diabetes 58: $1302-$ 1311.

Fallon PG, Ballantyne SJ, Mangan NE, Barlow JL, Dasvarma A, Hewett DR, McIlgorm A, Jolin HE, McKenzie AN. 2006. Identification of an interleukin (IL)-25-dependent cell population that provides IL-4, IL-5, and IL-13 at the onset of helminth expulsion. J Exp Med 203: 1105-1116.

Fort MM, Cheung J, Yen D, Li J, Zurawski SM, Lo S, Menon S, Clifford T, Hunte B, Lesley R, et al. 2001. IL-25 induces IL-4, IL-5, and IL-13 and Th2-associated pathologies in vivo. Immunity 15: 985-995.

Gaffen SL. 2009. Structure and signalling in the IL-17 receptor family. Nat Rev Immunol 9: 556-567.

Garg AV, Ahmed M, Vallejo AN, Ma A, Gaffen SL. 2013. The deubiquitinase A20 mediates feedback inhibition of interleukin-17 receptor signaling. Sci Signal 6: ra44.
Garg AV, Amatya N, Chen K, Cruz JA, Grover P, Whibley N, Conti HR, Hernandez Mir G, Sirakova T, Childs EC, et al. 2015. MCPIP1 endoribonuclease activity negatively regulates interleukin-17-mediated signaling and inflammation. Immunity 43: 475-487.

Genetic Analysis of Psoriasis Consortium \& the Wellcome Trust Case Control Consortium 2; Strange A, Capon F, Spencer CC, Knight J, Weale ME, Allen MH, Barton A, Band G, Bellenguez C, et al. 2010. A genome-wide association study identifies new psoriasis susceptibility loci and an interaction between HLA-C and ERAP1. Nat Genet 42: 985-990.

Golden JB, Wang Y, Fritz Y, Diaconu D, Zhang X, Debanne SM, Simon DI, McCormick TS, Ward NL. 2015. Chronic, not acute, skin-specific inflammation promotes thrombosis in psoriasis murine models. J Transl Med 13: 382.

Gordon KB, Blauvelt A, Papp KA, Langley RG, Luger T, Ohtsuki M, Reich K, Amato D, Ball SG, Braun DK, et al. 2016. Phase 3 trials of ixekizumab in moderate-tosevere plaque psoriasis. N Engl J Med 375: 345-356.

Ha HL, Wang H, Pisitkun P, Kim JC, Tassi I, Tang W, Morasso MI, Udey MC, Siebenlist U. 2014. IL-17 drives psoriatic inflammation via distinct, target cell-specific mechanisms. Proc Natl Acad Sci 111: E3422-E3431.

Harden JL, Krueger JG, Bowcock AM. 2015. The immunogenetics of psoriasis: A comprehensive review. J Autoimmun 64: 66-73.

He KL, Ting AT. 2002. A20 inhibits tumor necrosis factor (TNF) $\alpha$-induced apoptosis by disrupting recruitment of TRADD and RIP to the TNF receptor 1 complex in Jurkat T cells. Mol Cell Biol 22: 6034-6045.

He D, Wu L, Kim HK, Li H, Elmets CA, Xu H. 2006. CD8 ${ }^{+}$ IL-17-producing T cells are important in effector functions for the elicitation of contact hypersensitivity responses. J Immunol 177: 6852-6858.

He D, Li H, Yusuf N, Elmets CA, Athar M, Katiyar SK, Xu H. 2012. IL-17 mediated inflammation promotes tumor growth and progression in the skin. PLos ONE 7: e32126.

Hercus TR, Dhagat U, Kan WL, Broughton SE, Nero TL, Perugini M, Sandow JJ, D’Andrea RJ, Ekert PG, Hughes T, et al. 2013. Signalling by the $\beta c$ family of cytokines. $C y$ tokine Growth Factor Rev 24: 189-201.

Herjan T, Yao P, Qian W, Li X, Liu C, Bulek K, Sun D, Yang WP, Zhu J, He A, et al. 2013. HuR is required for IL-17induced Act1-mediated CXCL1 and CXCL5 mRNA stabilization. J Immunol 191: 640-649.

Hong YH, Lillehoj HS, Park DW, Lee SH, Han JY, Shin JH, Park MS, Kim JK. 2008. Cloning and functional characterization of chicken interleukin-17D. Vet Immunol Immunopathol 126: 1-8.

Hoshino A, Nagao T, Nagi-Miura N, Ohno N, Yasuhara M, Yamamoto K, Nakayama T, Suzuki K. 2008. MPO-ANCA induces IL-17 production by activated neutrophils in vitro via classical complement pathway-dependent manner. J Autoimmun 31: 79-89.

Huang CK, Yang CY, Jeng YM, Chen CL, Wu HH, Chang YC, Ma C, Kuo WH, Chang KJ, Shew JY, et al. 2014. Autocrine/paracrine mechanism of interleukin-17B receptor promotes breast tumorigenesis through NF-кB-mediated antiapoptotic pathway. Oncogene 33: 2968-2977. 
Huang XD, Zhang H, He MX. 2015. Comparative and evolutionary analysis of the interleukin 17 gene family in invertebrates. PLos ONE 10: $\mathrm{e} 0132802$.

Huber M, Heink S, Pagenstecher A, Reinhard K, Ritter J, Visekruna A, Guralnik A, Bollig N, Jeltsch K, Heinemann C, et al. 2013. IL-17A secretion by CD $8^{+} \mathrm{T}$ cells supports Th17-mediated autoimmune encephalomyelitis. J Clin Invest 123: 247-260.

Hüffmeier U, Uebe S, Ekici AB, Bowes J, Giardina E, Korendowych E, Juneblad K, Apel M, McManus R, Ho P, et al. 2010. Common variants at TRAF3IP2 are associated with susceptibility to psoriatic arthritis and psoriasis. Nat Genet 42: 996-999.

Hurst SD, Muchamuel T, Gorman DM, Gilbert JM, Clifford T, Kwan S, Menon S, Seymour B, Jackson C, Kung TT, et al. 2002. New IL-17 family members promote Th1 or Th2 responses in the lung: In vivo function of the novel cytokine IL-25. J Immunol 169: 443-453.

Hvid M, Vestergaard C, Kemp K, Christensen GB, Deleuran B, Deleuran M. 2011. IL-25 in atopic dermatitis: A possible link between inflammation and skin barrier dysfunction? J Invest Dermatol 131: 150-157.

Hwang SY, Kim HY. 2005. Expression of IL-17 homologs and their receptors in the synovial cells of rheumatoid arthritis patients. Mol Cell 19: 180-184.

Hymowitz SG, Filvaroff EH, Yin JP, Lee J, Cai L, Risser P, Maruoka M, Mao W, Foster J, Kelley RF, et al. 2001. IL-17s adopt a cystine knot fold: Structure and activity of a novel cytokine, IL-17F, and implications for receptor binding. EMBO J 20: 5332-5341.

Ippagunta SK, Gangwar R, Finkelstein D, Vogel P, Pelletier S Gingras S, Redecke V, Häcker H. 2016. Keratinocytes contribute intrinsically to psoriasis upon loss of Tnip 1 function. Proc Natl Acad Sci 113: E6162-E6171.

Ishigame $H$, Kakuta $S$, Nagai T, Kadoki M, Nambu A, Komiyama Y, Fujikado N, Tanahashi Y, Akitsu A, Kotaki H, et al. 2009. Differential roles of interleukin-17A and -17F in host defense against mucoepithelial bacterial infection and allergic responses. Immunity 30: 108-119.

Ivanov II, McKenzie BS, Zhou L, Tadokoro CE, Lepelley A, Lafaille JJ, Cua DJ, Littman DR. 2006. The orphan nuclear receptor ROR $\gamma t$ directs the differentiation program of proinflammatory IL-17 ${ }^{+}$T helper cells. Cell 126: $1121-$ 1133.

Iwakura Y, Ishigame H, Saijo S, Nakae S. 2011. Functional specialization of interleukin-17 family members. Immunity 34: 149-162.

Johansen C, Usher PA, Kjellerup RB, Lundsgaard D, Iversen L, Kragballe K. 2009. Characterization of the interleukin17 isoforms and receptors in lesional psoriatic skin. $\mathrm{Br}$ J Dermatol 160: 319-324.

Johnston A, Fritz Y, Dawes SM, Diaconu D, Al-Attar PM, Guzman AM, Chen CS, Fu W, Gudjonsson JE, McCormick TS, et al. 2013. Keratinocyte overexpression of IL-17C promotes psoriasiform skin inflammation. J Immunol 190: 2252-2262.

Kleinschek MA, Owyang AM, Joyce-Shaikh B, Langrish CL, Chen Y, Gorman DM, Blumenschein WM, McClanahan T, Brombacher F, Hurst SD, et al. 2007. IL-25 regulates Th17 function in autoimmune inflammation. J Exp Med 204: $161-170$.
Korn T, Oukka M, Kuchroo V, Bettelli E. 2007. Th17 cells: Effector T cells with inflammatory properties. Semin Immunol 19: 362-371.

Kouri VP, Olkkonen J, Ainola M, Li TF, Björkman L, Konttinen YT, Mandelin J. 2014. Neutrophils produce interleukin-17B in rheumatoid synovial tissue. Rheumatology 53: 39-47.

Kouzaki H, Tojima I, Kita H, Shimizu T. 2013. Transcription of interleukin-25 and extracellular release of the protein is regulated by allergen proteases in airway epithelial cells. Am J Respir Cell Mol Biol 49: 741-750.

Kronenberg M. 2005. Toward an understanding of NKT cell biology: Progress and paradoxes. Annu Rev Immunol 23: 877-900.

Kuestner RE, Taft DW, Haran A, Brandt CS, Brender T, Lum K, Harder B, Okada S, Ostrander CD, Kreindler JL, et al. 2007. Identification of the IL-17 receptor related molecule IL-17RC as the receptor for IL-17F. J Immunol 179: 5462-5473.

Langley RG, Elewski BE, Lebwohl M, Reich K, Griffiths CE, Papp K, Puig L, Nakagawa H, Spelman L, Sigurgeirsson B, et al. 2014. Secukinumab in plaque psoriasis-Results of two phase 3 trials. $N$ Engl J Med 371: 326-338.

Langrish CL, Chen Y, Blumenschein WM, Mattson J, Basham B, Sedgwick JD, McClanahan T, Kastelein RA, Cua DJ. 2005. IL-23 drives a pathogenic T cell population that induces autoimmune inflammation. J Exp Med 201: 233-240.

Lee J, Ho WH, Maruoka M, Corpuz RT, Baldwin DT, Foster JS, Goddard AD, Yansura DG, Vandlen RL, Wood WI, et al. 2001. IL-17E, a novel proinflammatory ligand for the IL-17 receptor homolog IL-17Rh1. I Biol Chem 276: 1660-1664.

Leonardi C, Matheson R, Zachariae C, Cameron G, Li L, Edson-Heredia E, Braun D, Banerjee S. 2012. Anti-interleukin-17 monoclonal antibody ixekizumab in chronic plaque psoriasis. N Engl J Med 366: 1190-1199.

Leonardi S, Cuppari C, Manti S, Filippelli M, Parisi GF, Borgia F, Briuglia S, Cannavò P, Salpietro A, Arrigo T, et al. 2015. Serum interleukin 17, interleukin 23, and interleukin 10 values in children with atopic eczema/dermatitis syndrome (AEDS): Association with clinical severity and phenotype. Allergy Asthma Proc 36: 74-81.

Li H, Chen J, Huang A, Stinson J, Heldens S, Foster J, Dowd P, Gurney AL, Wood WI. 2000. Cloning and characterization of IL-17B and IL-17C, two new members of the IL17 cytokine family. Proc Natl Acad Sci 97: 773-778.

Li L, Huang L, Vergis AL, Ye H, Bajwa A, Narayan V, Strieter RM, Rosin DL, Okusa MD. 2010. IL-17 produced by neutrophils regulates IFN- $\gamma$-mediated neutrophil migration in mouse kidney ischemia-reperfusion injury. J Clin Invest 120: 331-342.

Liang SC, Tan XY, Luxenberg DP, Karim R, Dunussi-Joannopoulos K, Collins M, Fouser LA. 2006. Interleukin (IL)-22 and IL-17 are coexpressed by Th17 cells and cooperatively enhance expression of antimicrobial peptides. J Exp Med 203: 2271-2279.

Lin Y, Ritchea S, Logar A, Slight S, Messmer M, RangelMoreno J, Guglani L, Alcorn JF, Strawbridge H, Park $\mathrm{SM}$, et al. 2009. Interleukin-17 is required for $\mathrm{T}$ helper 1 cell immunity and host resistance to the intracellular pathogen Francisella tularensis. Immunity 31: 799-810. 
Lin AM, Rubin CJ, Khandpur R, Wang JY, Riblett M, Yalavarthi S, Villanueva EC, Shah P, Kaplan MJ, Bruce AT. 2011. Mast cells and neutrophils release IL-17 through extracellular trap formation in psoriasis. J Immunol 187: 490-500.

Liu J, Feng Y, Yang K, Li Q, Ye L, Han L, Wan H. 2011. Early production of IL-17 protects against acute pulmonary Pseudomonas aeruginosa infection in mice. FEMS Immunol Med Microbiol 61: 179-188.

Liu S, Song X, Chrunyk BA, Shanker S, Hoth LR, Marr ES, Griffor MC. 2013. Crystal structures of interleukin 17A and its complex with IL-17 receptor A. Nat Commun 4: 1888.

Luo H, Liu Y, Li Q, Liao L, Sun R, Liu X, Jiang M, Hu J. 2015. A20 regulates IL-1-induced tolerant production of CXC chemokines in human mesangial cells via inhibition of MAPK signaling. Sci Rep 5: 18007.

Maezawa Y, Nakajima H, Suzuki K, Tamachi T, Ikeda K, Inoue J, Saito Y, Iwamoto I. 2006. Involvement of TNF receptor-associated factor 6 in IL-25 receptor signaling. $J$ Immunol 176: 1013-1018.

Mangan PR, Harrington LE, O'Quinn DB, Helms WS, Bullard DC, Elson CO, Hatton RD, Wahl SM, Schoeb TR, Weaver CT. 2006. Transforming growth factor- $\beta$ induces development of the $\mathrm{T}_{\mathrm{H}} 17$ lineage. Nature 441: 231-234.

Manni ML, Robinson KM, Alcorn JF. 2014. A tale of two cytokines: IL-17 and IL-22 in asthma and infection. Exp Rev Respir Med 8: 25-42.

Marks BR, Nowyhed HN, Choi JY, Poholek AC, Odegard JM, Flavell RA, Craft J. 2009. Thymic self-reactivity selects natural interleukin 17-producing $\mathrm{T}$ cells that can regulate peripheral inflammation. Nat Immunol 10: 1125-1132.

McGeachy MJ, Chen Y, Tato CM, Laurence A, Joyce-Shaikh B, Blumenschein WM, McClanahan TK, O'Shea JJ, Cua DJ. 2009. The interleukin 23 receptor is essential for the terminal differentiation of interleukin 17-producing effector T helper cells in vivo. Nat Immunol 10: 314-324.

McHenga SS, Wang D, Li C, Shan F, Lu C. 2008. Inhibitory effect of recombinant IL- 25 on the development of dextran sulfate sodium-induced experimental colitis in mice. Cell Mol Immunol 5: 425-431.

Milner JD, Holland SM. 2013. The cup runneth over: Lessons from the ever-expanding pool of primary immunodeficiency diseases. Nat Rev Immunol 13: 635-648.

Monin L, Gudjonsson JE, Childs EE, Amatya N, Xing X, Verma AH, Coleman BM, Garg AV, Killeen M, Mathers A, et al. 2017. MCPIP1/regnase-1 restricts IL-17A- and IL-17C-dependent skin inflammation. J Immunol 198: 767-775.

Morita H, Arae K, Unno H, Toyama S, Motomura K, Matsuda A, Suto H, Okumura K, Sudo K, Takahashi T, et al. 2015. IL-25 and IL-33 Contribute to development of eosinophilic airway inflammation in epicutaneously antigen-sensitized mice. PLos ONE 10: e0134226.

Moro K, Yamada T, Tanabe M, Takeuchi T, Ikawa T, Kawamoto H, Furusawa J, Ohtani M, Fujii H, Koyasu S. 2010. Innate production of $\mathrm{T}_{\mathrm{H}} 2$ cytokines by adipose tissueassociated c-Kit ${ }^{+} \mathrm{Sca}-1^{+}$lymphoid cells. Nature 463: $540-544$.

Mosmann TR, Cherwinski H, Bond MW, Giedlin MA, Coffman RL. 1986. Two types of murine helper T cell clone. I: Definition according to profiles of lymphokine activities and secreted proteins. J Immunol 136: 2348 2357.

Nakae S, Komiyama Y, Nambu A, Sudo K, Iwase M, Homma I, Sekikawa K, Asano M, Iwakura Y. 2002. Antigen-specific $\mathrm{T}$ cell sensitization is impaired in IL-17-deficient mice, causing suppression of allergic cellular and humoral responses. Immunity 17: 375-387.

Neill DR, Wong SH, Bellosi A, Flynn RJ, Daly M, Langford TK, Bucks C, Kane CM, Fallon PG, Pannell R, et al. 2010. Nuocytes represent a new innate effector leukocyte that mediates type-2 immunity. Nature 464: 1367-1370.

Nestle FO, Kaplan DH, Barker J. 2009. Psoriasis. N Engl J Med 361: 496-509.

Nograles KE, Zaba LC, Guttman-Yassky E, Fuentes-Duculan J, Suarez-Farinas M, Cardinale I, Fuentes-Duculan J, Suárez-Fariñas M, Cardinale I, Khatcherian A, et al. 2008. Th17 cytokines interleukin (IL)-17 and IL-22 modulate distinct inflammatory and keratinocyte-response pathways. Br J Dermatol 159: 1092-1102.

Noordenbos T, Blijdorp I, Chen S, Stap J, Mul E, Cañete JD, Lubberts E, Yeremenko N, Baeten D. 2016. Human mast cells capture, store, and release bioactive, exogenous IL17A. J Leukoc Biol 100: 453-462.

Novatchkova M, Leibbrandt A, Werzowa J, Neubuser A, Eisenhaber F. 2003. The STIR-domain superfamily in signal transduction, development and immunity. Trends Biochem Sci 28: 226-229.

Nurieva R, Yang XO, Martinez G, Zhang Y, Panopoulos AD, Ma L, Schluns K, Tian Q, Watowich SS, Jetten AM, et al. 2007. Essential autocrine regulation by IL-21 in the generation of inflammatory T cells. Nature 448: 480-483.

Onishi RM, Gaffen SL. 2010. Interleukin-17 and its target genes: Mechanisms of interleukin-17 function in disease. Immunology 129: 311-321.

O'Sullivan T, Saddawi-Konefka R, Gross E, Tran M, Mayfield SP, Ikeda H, Bui JD. 2014. Interleukin-17D mediates tumor rejection through recruitment of natural killer cells. Cell Rep 7: 989-998.

Owyang AM, Zaph C, Wilson EH, Guild KJ, McClanahan T, Miller HR, Cua DJ, Goldschmidt M, Hunter CA, Kastelein RA, et al. 2006. Interleukin 25 regulates type 2 cytokine-dependent immunity and limits chronic inflammation in the gastrointestinal tract. J Exp Med 203: 843-849.

Ozaki K, Leonard WJ. 2002. Cytokine and cytokine receptor pleiotropy and redundancy. J Biol Chem 277: 2935529358.

Palmer CN, Irvine AD, Terron-Kwiatkowski A, Zhao Y, Liao H, Lee SP, Goudie DR, Sandilands A, Campbell LE, Smith FJ, et al. 2006. Common loss-of-function variants of the epidermal barrier protein filaggrin are a major predisposing factor for atopic dermatitis. Nat Genet 38: 441-446.

Pan G, French D, Mao W, Maruoka M, Risser P, Lee J, Foster J, Aggarwal S, Nicholes K, Guillet S, et al. 2001. Forced expression of murine IL-17E induces growth retardation, jaundice, a Th2-biased response, and multiorgan inflammation in mice. J Immunol 167: 6559-6567.

Park H, Li Z, Yang XO, Chang SH, Nurieva R, Wang YH, Wang Y, Hood L, Zhu Z, Tian Q, et al. 2005. A distinct lineage of $\mathrm{CD} 4 \mathrm{~T}$ cells regulates tissue inflammation by producing interleukin 17. Nat Immunol 6: 1133-1141. 
Price AE, Liang HE, Sullivan BM, Reinhardt RL, Eisley CJ, Erle DJ, Locksley RM. 2010. Systemically dispersed innate IL-13-expressing cells in type 2 immunity. Proc Natl Acad Sci 107: 11489-11494.

Puel A, Döffinger R, Natividad A, Chrabieh M, BarcenasMorales G, Picard C, Cobat A, Ouachée-Chardin M, Toulon A, Bustamante J, et al. 2010. Autoantibodies against IL-17A, IL-17F, and IL-22 in patients with chronic mucocutaneous candidiasis and autoimmune polyendocrine syndrome type I. J Exp Med 207: 291-297.

Puel A, Cypowyj S, Bustamante J, Wright JF, Liu L, Lim HK, Migaud M, Israel L, Chrabieh M, Audry M, et al. 2011. Chronic mucocutaneous candidiasis in humans with inborn errors of interleukin-17 immunity. Science 332: 6568.

Qian Y, Liu C, Hartupee J, Altuntas CZ, Gulen MF, Jane-Wit D, Xiao J, Lu Y, Giltiay N, Liu J, et al. 2007. The adaptor Act1 is required for interleukin 17-dependent signaling associated with autoimmune and inflammatory disease. Nat Immunol 8: 247-256.

Qu F, Gao H, Zhu S, Shi P, Zhang Y, Liu Y, Jallal B, Yao Y, Shi Y, Qian Y. 2012. TRAF6-dependent Act1 phosphorylation by the IкB kinase-related kinases suppresses interleukin17-induced NF- $\mathrm{KB}$ activation. Mol Cell Biol 32: 39253937.

Ramirez-Carrozzi V, Sambandam A, Luis E, Lin Z, Jeet S, Lesch J, Hackney J, Kim J, Zhou M, Lai J, et al. 2011. IL17C regulates the innate immune function of epithelial cells in an autocrine manner. Nat Immunol 12: 11591166.

Reynolds JM, Lee YH, Shi Y, Wang X, Angkasekwinai P, Nallaparaju KC, Flaherty S, Chang SH, Watarai H, Dong C. 2015. Interleukin-17B antagonizes interleukin-25-mediated mucosal inflammation. Immunity 42: 692-703.

Rickel EA, Siegel LA, Yoon BR, Rottman JB, Kugler DG, Swart DA, Anders PM, Tocker JE, Comeau MR, Budelsky AL. 2008. Identification of functional roles for both IL17RB and IL-17RA in mediating IL-25-induced activities. J Immunol 181: 4299-4310.

Roth SA, Simanski M, Rademacher F, Schroder L, Harder J. 2014. The pattern recognition receptor NOD2 mediates Staphylococcus aureus-induced IL-17C expression in keratinocytes. J Invest Dermatol 134: 374-380.

Rouvier E, Luciani MF, Mattei MG, Denizot F, Golstein P. 1993. CTLA-8, cloned from an activated T cell, bearing AU-rich messenger RNA instability sequences, and homologous to a herpesvirus saimiri gene. J Immunol 150: 5445-5456.

Ruddy MJ, Wong GC, Liu XK, Yamamoto H, Kasayama S, Kirkwood KL, Gaffen SL. 2004. Functional cooperation between interleukin-17 and tumor necrosis factor- $\alpha$ is mediated by CCAAT/enhancer-binding protein family members. J Biol Chem 279: 2559-2567.

Saadoun D, Terrier B, Cacoub P. 2011. Interleukin-25: Key regulator of inflammatory and autoimmune diseases. Curr Pharm Des 17: 3781-3785.

Saddawi-Konefka R, O'Sullivan T, Gross ET, Washington AJr, Bui JD. 2014. Tumor-expressed IL-17D recruits NK cells to reject tumors. Oncoimmunology 3: e954853.

Saddawi-Konefka R, Seelige R, Gross ET, Levy E, Searles SC, Washington AJr, Santosa EK, Liu B, O’Sullivan TE, Har- ismendy O, et al. 2016. Nrf2 induces IL-17D to mediate tumor and virus surveillance. Cell Rep 16: 2348-2358.

Salimi M, Barlow JL, Saunders SP, Xue L, Gutowska-Owsiak D, Wang X, Huang LC, Johnson D, Scanlon ST, McKenzie AN, et al. 2013. A role for IL-25 and IL-33-driven type-2 innate lymphoid cells in atopic dermatitis. J Exp Med 210: 2939-2950.

Sanford M, McKeage K. 2015. Secukinumab: First global approval. Drugs 75: 329-338.

Schultz Larsen F. 1996. Atopic dermatitis: An increasing problem. Pediatr Allergy Immunol 7: 51-53.

Schwandner R, Yamaguchi K, Cao Z. 2000. Requirement of tumor necrosis factor receptor-associated factor (TRAF)6 in interleukin 17 signal transduction. J Exp Med 191: 1233-1240.

Shen F, Ruddy MJ, Plamondon P, Gaffen SL. 2005. Cytokines link osteoblasts and inflammation: Microarray analysis of interleukin-17- and TNF- $\alpha$-induced genes in bone cells. J Leukoc Biol 77: 388-399.

Shen F, Li N, Gade P, Kalvakolanu DV, Weibley T, Doble B, Woodgett JR, Wood TD, Gaffen SL. 2009. IL-17 receptor signaling inhibits $\mathrm{C} / \mathrm{EBP} \beta$ by sequential phosphorylation of the regulatory 2 domain. Sci Signal 2: ra8.

Shi Y, Ullrich SJ, Zhang J, Connolly K, Grzegorzewski KJ, Barber MC, Wang W, Wathen K, Hodge V, Fisher CL, et al. 2000. A novel cytokine receptor-ligand pair. Identification, molecular characterization, and in vivo immunomodulatory activity. J Biol Chem 275: 19167-19176.

Somma D, Mastrovito P, Grieco M, Lavorgna A, Pignalosa A, Formisano L, Salzano AM, Scaloni A, Pacifico F, Siebenlist U, et al. 2015. CIKS/DDX3X interaction controls the stability of the Zc3h12a mRNA induced by IL-17. J Immunol 194: 3286-3294.

Sonder SU, Saret S, Tang W, Sturdevant DE, Porcella SF, Siebenlist U. 2011. IL-17-induced NF-кB activation via CIKS/Act1: Physiologic significance and signaling mechanisms. J Biol Chem 286: 12881-12890.

Sonder SU, Paun A, Ha HL, Johnson PF, Siebenlist U. 2012. CIKS/Act1-mediated signaling by IL-17 cytokines in context: Implications for how a CIKS gene variant may predispose to psoriasis. J Immunol 188: 5906-5914.

Song X, Zhu S, Shi P, Liu Y, Shi Y, Levin SD, Qian Y. 2011. IL$17 \mathrm{RE}$ is the functional receptor for IL-17C and mediates mucosal immunity to infection with intestinal pathogens. Nat Immunol 12: 1151-1158.

Song X, He X, Li X, Qian Y. 2016. The roles and functional mechanisms of interleukin-17 family cytokines in mucosal immunity. Cell Mol Immunol 13: 418-431.

Starnes T, Broxmeyer HE, Robertson MJ, Hromas R. 2002. Cutting edge: IL-17D, a novel member of the IL-17 family, stimulates cytokine production and inhibits hemopoiesis. J Immunol 169: 642-646.

Steinman L. 2007. A brief history of $\mathrm{T}_{\mathrm{H}} 17$, the first major revision in the $\mathrm{T}_{\mathrm{H}} 1 / \mathrm{T}_{\mathrm{H}} 2$ hypothesis of $\mathrm{T}$ cell-mediated tissue damage. Nat Med 13: 139-145.

Sun D, Novotny M, Bulek K, Liu C, Li X, Hamilton T. 2011. Treatment with IL-17 prolongs the half-life of chemokine CXCL1 mRNA via the adaptor TRAF5 and the splicingregulatory factor SF2 (ASF). Nat Immunol 12: 853-860.

Swaidani S, Bulek K, Kang Z, Liu C, Lu Y, Yin W, Aronica M, Li X. 2009. The critical role of epithelial-derived Act1 in 
IL-17- and IL-25-mediated pulmonary inflammation. $J$ Immunol 182: 1631-1640.

Toy D, Kugler D, Wolfson M, Vanden Bos T, Gurgel J, Derry J, Tocker J, Peschon J. 2006. Cutting edge: Interleukin 17 signals through a heteromeric receptor complex. J Immunol 177: 36-39.

Tsoi LC, Spain SL, Knight J, Ellinghaus E, Stuart PE, Capon F, Ding J, Li Y, Tejasvi T, Gudjonsson JE, et al. 2012. Identification of 15 new psoriasis susceptibility loci highlights the role of innate immunity. Nat Genet 44: 13411348.

van der Fits L, Mourits S, Voerman JS, Kant M, Boon L, Laman JD, Cornelissen F, Mus AM, Florencia E, Prens EP, et al. 2009. Imiquimod-induced psoriasis-like skin inflammation in mice is mediated via the IL-23/IL-17 axis. J Immunol 182: 5836-5845.

Veldhoen M, Hocking RJ, Atkins CJ, Locksley RM, Stockinger B. 2006. TGF $\beta$ in the context of an inflammatory cytokine milieu supports de novo differentiation of IL17-producing T cells. Immunity 24: 179-189.

Villanova F, Flutter B, Tosi I, Grys K, Sreeneebus H, Perera GK, Chapman A, Smith CH, Di Meglio P, Nestle FO. 2014. Characterization of innate lymphoid cells in human skin and blood demonstrates increase of NKp44 ILC3 in psoriasis. J Invest Dermatol 134: 984-991.

Wang YH, Angkasekwinai P, Lu N, Voo KS, Arima K, Hanabuchi S, Hippe A, Corrigan CJ, Dong C, Homey B, et al. 2007. IL-25 augments type 2 immune responses by enhancing the expansion and functions of TSLP-DC-activated Th2 memory cells. J Exp Med 204: 1837-1847.

Wang L, Yi T, Zhang W, Pardoll DM, Yu H. 2010. IL-17 enhances tumor development in carcinogen-induced skin cancer. Cancer Res 70: 10112-10120.

Wang C, Wu L, Bulek K, Martin BN, Zepp JA, Kang Z, Liu C, Herjan T, Misra S, Carman JA, et al. 2013. The psoriasisassociated D10N variant of the adaptor Actl with impaired regulation by the molecular chaperone hsp90. Nat Immunol 14: 72-81.

Weidinger S, Illig T, Baurecht $\mathrm{H}$, Irvine $\mathrm{AD}$, Rodriguez $\mathrm{E}$, Diaz-Lacava A, Klopp N, Wagenpfeil S, Zhao Y, Liao H, et al. 2006. Loss-of-function variations within the filaggrin gene predispose for atopic dermatitis with allergic sensitizations. J Allergy Clin Immunol 118: 214-219.

Whibley N, Tritto E, Traggiai E, Kolbinger F, Moulin P, Brees D, Coleman BM, Mamo AJ, Garg AV, Jaycox JR, et al. 2016. Antibody blockade of IL-17 family cytokines in immunity to acute murine oral mucosal candidiasis. J Leukoc Biol 99: 1153-1164.

Wilson NJ, Boniface K, Chan JR, McKenzie BS, Blumenschein WM, Mattson JD, Basham B, Smith K, Chen T, Morel F, et al. 2007. Development, cytokine profile and function of human interleukin 17-producing helper T cells. Nat Immunol 8: 950-957.

Wright JF, Guo Y, Quazi A, Luxenberg DP, Bennett F, Ross JF, Qiu Y, Whitters MJ, Tomkinson KN, Dunussi-Joanno- poulos $\mathrm{K}$, et al. 2007. Identification of an interleukin $17 \mathrm{~F} / 17 \mathrm{~A}$ heterodimer in activated human $\mathrm{CD} 4^{+} \mathrm{T}$ cells. J Biol Chem 282: 13447-13455.

Wu HH, Hwang-Verslues WW, Lee WH, Huang CK, Wei PC, Chen CL, Shew JY, Lee EY, Jeng YM, Tien YW, et al. 2015a. Targeting IL-17B-IL-17RB signaling with an antiIL-17RB antibody blocks pancreatic cancer metastasis by silencing multiple chemokines. J Exp Med 212: 333-349.

Wu L, Zepp JA, Qian W, Martin BN, Ouyang W, Yin W, Bunting KD, Aronica M, Erzurum S, Li X. 2015b. A novel IL-25 signaling pathway through STAT5. J Immunol 194: $4528-4534$.

Yang D, Chertov O, Bykovskaia SN, Chen Q, Buffo MJ, Shogan J, Anderson M, Schröder JM, Wang JM, Howard OM, et al. 1999. $\beta$-Defensins: Linking innate and adaptive immunity through dendritic and T cell CCR6. Science 286: 525-528.

Yang J, Goetz D, Li JY, Wang W, Mori K, Setlik D, Du T, Erdjument-Bromage H, Tempst P, Strong R, et al. 2002. An iron delivery pathway mediated by a lipocalin. $\mathrm{Mol}$ Cell 10: 1045-1056.

Yao Z, Fanslow WC, Seldin MF, Rousseau AM, Painter SL, Comeau MR, Cohen JI, Spriggs MK. 1995. Herpesvirus Saimiri encodes a new cytokine, IL-17, which binds to a novel cytokine receptor. Immunity 3: 811-821.

Ye P, Garvey PB, Zhang P, Nelson S, Bagby G, Summer WR, Schwarzenberger P, Shellito JE, Kolls JK. 2001. Interleukin-17 and lung host defense against Klebsiella pneumoniae infection. Am J Respir Cell Mol Biol 25: 335-340.

You Z, DuRaine G, Tien JY, Lee C, Moseley TA, Reddi AH. 2005. Expression of interleukin-17B in mouse embryonic limb buds and regulation by BMP-7 and bFGF. Biochem Biophys Res Commun 326: 624-631.

Zepp JA, Liu C, Qian W, Wu L, Gulen MF, Kang Z, Li X. 2012. Cutting edge: TNF receptor-associated factor 4 restricts IL-17-mediated pathology and signaling processes. J Immunol 189: 33-37.

Zepp JA, Wu L, Qian W, Ouyang W, Aronica M, Erzurum S, Li X. 2015. TRAF4-SMURF2-mediated DAZAP2 degradation is critical for IL-25 signaling and allergic airway inflammation. J Immunol 194: 2826-2837.

Zhou L, Ivanov, II, Spolski R, Min R, Shenderov K, Egawa T, Levy DE, Leonard WJ, Littman DR. 2007. IL-6 programs $\mathrm{T}_{\mathrm{H}^{-1}} 17$ cell differentiation by promoting sequential engagement of the IL-21 and IL-23 pathways. Nat Immunol 8: $967-974$.

Zhu S, Pan W, Shi P, Gao H, Zhao F, Song X, Liu Y, Zhao L, Li X, Shi Y, et al. 2010. Modulation of experimental autoimmune encephalomyelitis through TRAF3-mediated suppression of interleukin 17 receptor signaling. J Exp Med 207: 2647-2662.

Zrioual S, Ecochard R, Tournadre A, Lenief V, Cazalis MA, Miossec P. 2009. Genome-wide comparison between IL17A- and IL-17F-induced effects in human rheumatoid arthritis synoviocytes. J Immunol 182: 3112-3120. 


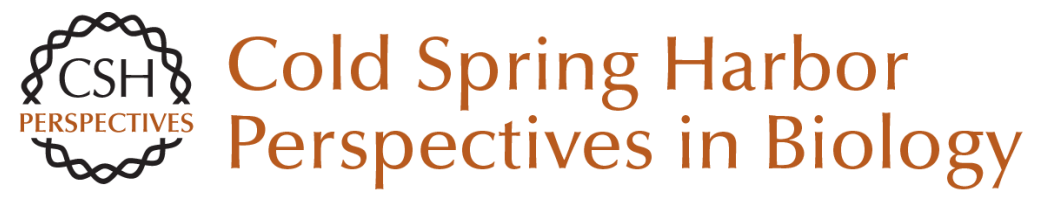

\title{
Interleukin 17 Family Cytokines: Signaling Mechanisms, Biological Activities, and Therapeutic Implications
}

\author{
Leticia Monin and Sarah L. Gaffen
}

Cold Spring Harb Perspect Biol 2018; doi: 10.1101/cshperspect.a028522 originally published online June 15,2017

\section{Subject Collection Cytokines}

Interleukin (IL)-33 and the IL-1 Family of Cytokines

--Regulators of Inflammation and Tissue

Homeostasis

Ajithkumar Vasanthakumar and Axel Kallies

Targeting IL-10 Family Cytokines for the Treatment of Human Diseases

Xiaoting Wang, Kit Wong, Wenjun Ouyang, et al.

Cytokine-Mediated Regulation of CD8 T-Cell Responses During Acute and Chronic Viral Infection

Masao Hashimoto, Se Jin Im, Koichi Araki, et al.

Cytokines in Cancer Immunotherapy

Thomas A. Waldmann

The Tumor Necrosis Factor Family: Family Conventions and Private Idiosyncrasies David Wallach

The Interferon (IFN) Class of Cytokines and the IFN Regulatory Factor (IRF) Transcription Factor Family

Hideo Negishi, Tadatsugu Taniguchi and Hideyuki

Yanai
Interferon $\gamma$ and Its Important Roles in Promoting and Inhibiting Spontaneous and Therapeutic Cancer Immunity

Elise Alspach, Danielle M. Lussier and Robert D. Schreiber

Inflammasome-Dependent Cytokines at the Crossroads of Health and Autoinflammatory Disease

Hanne Van Gorp, Nina Van Opdenbosch and Mohamed Lamkanfi

Innate Lymphoid Cells (ILCs): Cytokine Hubs

Regulating Immunity and Tissue Homeostasis Maho Nagasawa, Hergen Spits and Xavier Romero Ros

T Helper Cell Differentiation, Heterogeneity, and

Plasticity Jinfang Zhu

Development, Diversity, and Function of Dendritic

Cells in Mouse and Human

David A. Anderson III, Kenneth M. Murphy and Carlos G. Briseño

Cytokines and Long Noncoding RNAs Susan Carpenter and Katherine A. Fitzgerald

For additional articles in this collection, see http://cshperspectives.cshlp.org/cgi/collection/

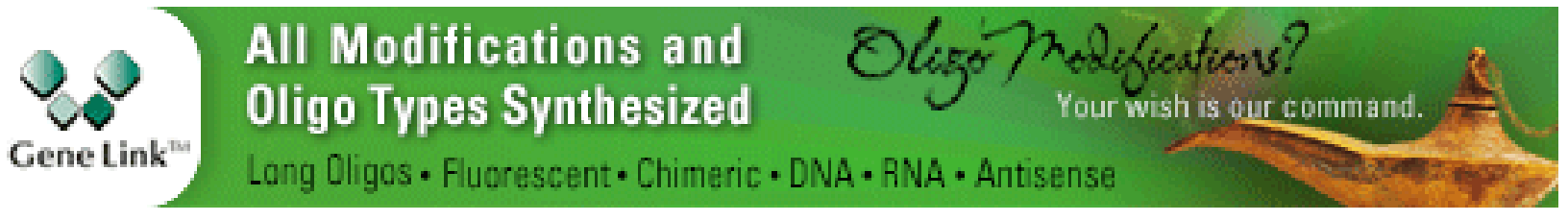


Role of the $\beta$ Common $(\beta \mathrm{c})$ Family of Cytokines in Health and Disease

Timothy R. Hercus, Winnie L. T. Kan, Sophie E. Broughton, et al.

Interleukin (IL)-12 and IL-23 and Their Conflicting Roles in Cancer Juming Yan, Mark J. Smyth and Michele W.L. Teng
Negative Regulation of Cytokine Signaling in Immunity

Akihiko Yoshimura, Minako Ito, Shunsuke Chikuma, et al.

Cancer Inflammation and Cytokines

Maria Rosaria Galdiero, Gianni Marone and Alberto Mantovani

For additional articles in this collection, see http://cshperspectives.cshlp.org/cgi/collection/

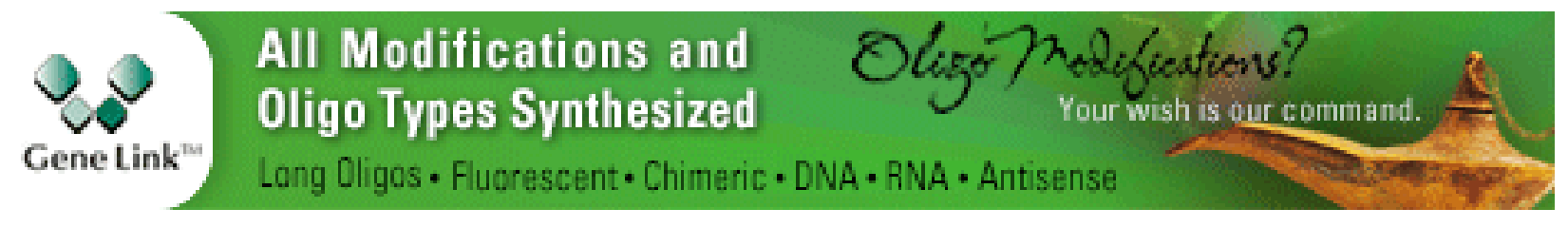

Copyright @ 2018 Cold Spring Harbor Laboratory Press; all rights reserved 